
Creative Commons Attribution licence (http://creativecommons. org/licenses/by/4.0/), which permits unrestricted re-use, distribution, and reproduction in any medium, provided the original work is properly cited.

\title{
REVIEW
}

\section{Renewable hydrogen for the chemical industry}

Nigel Rambhujun, Muhammad Saad Salman, Ting Wang, Chulaluck Pratthana, Prabal Sapkota, Mehdi Costalin, Qiwen Lai, and Kondo-Francois Aguey-Zinsou, MERLin, School of Chemical Engineering, The University of New South Wales, Sydney, NSW 2052, Australia Address all correspondence to Kondo-Francois Aguey-Zinsou at f.aguey@ unsw.edu.au

(Received 19 June 2020; accepted 18 August 2020)

\section{ABSTRACT}

Hydrogen is often touted as the fuel of the future, but hydrogen is already an important feedstock for the chemical industry. This review highlights current means for hydrogen production and use, and the importance of progressing $R \& D$ along key technologies and policies to drive a cost reduction in renewable hydrogen production and enable the transition of chemical manufacturing toward green hydrogen as a feedstock and fuel.

The chemical industry is at the core of what is considered a modern economy. It provides commodities and important materials, e.g., fertilizers, synthetic textiles, and drug precursors, supporting economies and more broadly our needs. The chemical sector is to become the major driver for oil production by 2030 as it entirely relies on sufficient oil supply. In this respect, renewable hydrogen has an important role to play beyond its use in the transport sector. Hydrogen not only has three times the energy density of natural gas and using hydrogen as a fuel could help decarbonize the entire chemical manufacturing, but also the use of green hydrogen as an essential reactant at the basis of many chemical products could facilitate the convergence toward virtuous circles. Enabling the production of green hydrogen at cost could not only enable new opportunities but also strengthen economies through a localized production and use of hydrogen. Herein, existing technologies for the production of renewable hydrogen including biomass and water electrolysis, and methods for the effective storage of hydrogen are reviewed with an emphasis on the need for mitigation strategies to enable such a transition.

Key words: chemical synthesis; circular economy; energy generation; energy storage; environment; environmentally protective; sustainability

\section{Introduction}

\section{Hydrogen in the chemical industry}

Hydrogen $\left(\mathrm{H}_{2}\right)$ is an important component of the universe with an enormous extent of applications. However, it does not

\section{DISCUSSION POINTS}

- Hydrogen is already an important feedstock supporting the chemical industry, and this makes the transition away from fossil fuels challenging.

- Green hydrogen could help decarbonize the chemical industry and beyond transform the industry toward "green" products

manufacturing.

- What is the current status, and which technologies could support such a transition? What is the role of policy in this? exist in free form in nature, but rather is bonded inside ubiquitous compounds such as water and hydrocarbons. As a key building block in chemical processes, a huge fraction of current hydrogen production is used in industrial processes such as the synthesis of ammonia and petrochemicals. The global demand for hydrogen, which has tripled since 1975, is growing every year with no signs of slowing down (Fig. 1). As of 2018 , the worldwide annual hydrogen production is estimated to be $\sim 74 \mathrm{Mt}$, with up to $\sim 96 \%$ used in the chemical industry, $\sim 42 \%$ alone for ammonia production, and $\sim 52 \%$ in different refineries. ${ }^{1}$ The remaining hydrogen $(\sim 6 \%)$ is used in other sectors such as glass production and reduction of iron ores (Figs. 1 and 2).

In the chemical industry, ammonia is globally produced through the well-known Haber-Bosch process, in which hydrogen and atmospheric nitrogen are passed over a catalyst at elevated temperatures and pressures. Ammonia is used extensively in agriculture, explosives, and cleaning streams. 


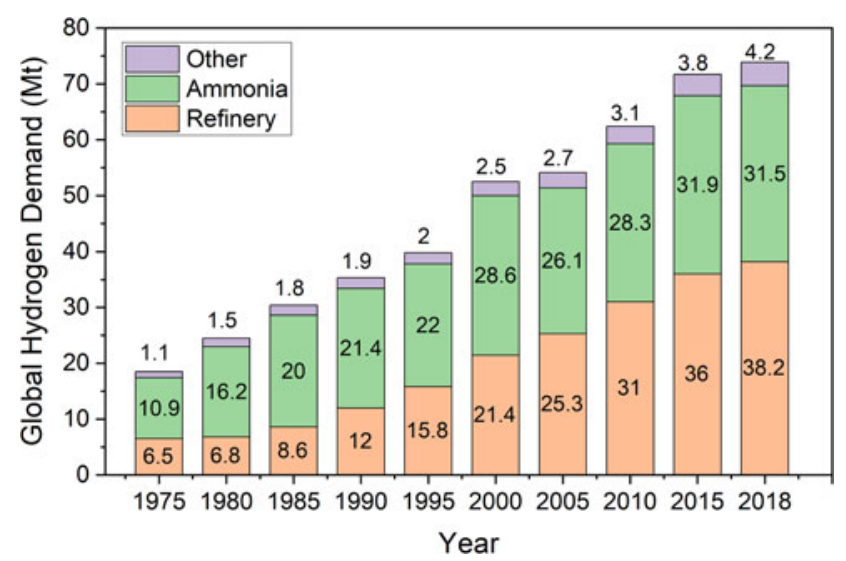

Figure 1. Global demand of pure hydrogen in refinery, ammonia, and other sectors for the period 1975-2018. Source: IEA. All rights reserved. ${ }^{1}$

Common nitrogen-rich fertilizers including urea and ammonium nitrate are produced directly from ammonia. Urea is obtained after reacting ammonia with $\mathrm{CO}_{2}$ originating from the steam reforming, while ammonium nitrate is produced through the catalytic oxidation of ammonia with nitric acid. As a carbon-free commodity, ammonia has been touted as a promising alternative to conventional hydrogen storage systems. ${ }^{2}$ However, most of the hydrogen for its production comes from fossil fuels through reforming - which collectively accounts for $830 \mathrm{Mt} \mathrm{CO}_{2} / \mathrm{yr}$ globally. ${ }^{1,3}$ The chemical industry, with $10 \%$ of the global energy consumption and $7 \%$ of the greenhouse gas emissions, ${ }^{4}$ is also the largest user of energy in the industry sector. Enabling the use of renewable hydrogen could thus have a significant impact in decarbonizing the industry sector. Renewables for green hydrogen production include solar and wind coupled with water electrolysis, solar-thermal, and in a distant future direct photochemical hydrogen generation. However, at the moment, the amount of renewable hydrogen is far from meeting the global needs for hydrogen (Fig. 2).

In the refinery sector, which is one of the biggest consumers, hydrogen is used in upgrading the hydrocarbons. Hydrogen is used to remove sulfur, halides, oxygen, metals, and/or nitrogen impurities, and cracking of heavier to lightweight hydrocarbons to produce many value-added chemicals. Most of these processes need careful conditions with suitable catalysts, which dictate the efficiency of the process.

Many chemical industries also use hydrogen extensively to reduce the degree of unsaturation, taste, and/or odor in fats and oils via a hydrogenation process carried out in the presence of nickel catalysts. ${ }^{5,6}$ This process increases the melting point and enhances the resistance to oxidation with prolonged preservation. In the hydrogenation process, the amount of hydrogen consumed depends on the oil and the degree of hardness (measured by the reduction in iodine number - that is the amount of hydrogen gas equivalent to iodine absorbed), the purity of hydrogen, and the equipment. Assuming that high-quality hydrogen is used, the actual amount of gas required is often $\sim 110 \%$ higher than the theoretical values. ${ }^{7}$

The hydrogenation of fats produces trans fats, which have adverse health effects, ${ }^{8}$ but recently, new chemistry has revealed that the formation of trans fats could be avoided by carefully manipulating the selectivity of the catalysts. ${ }^{9}$ It is expected that such selective catalytic hydrogenation processes will be further developed in the future and could help to lower the pernicious effects of saturated fats. ${ }^{10}$

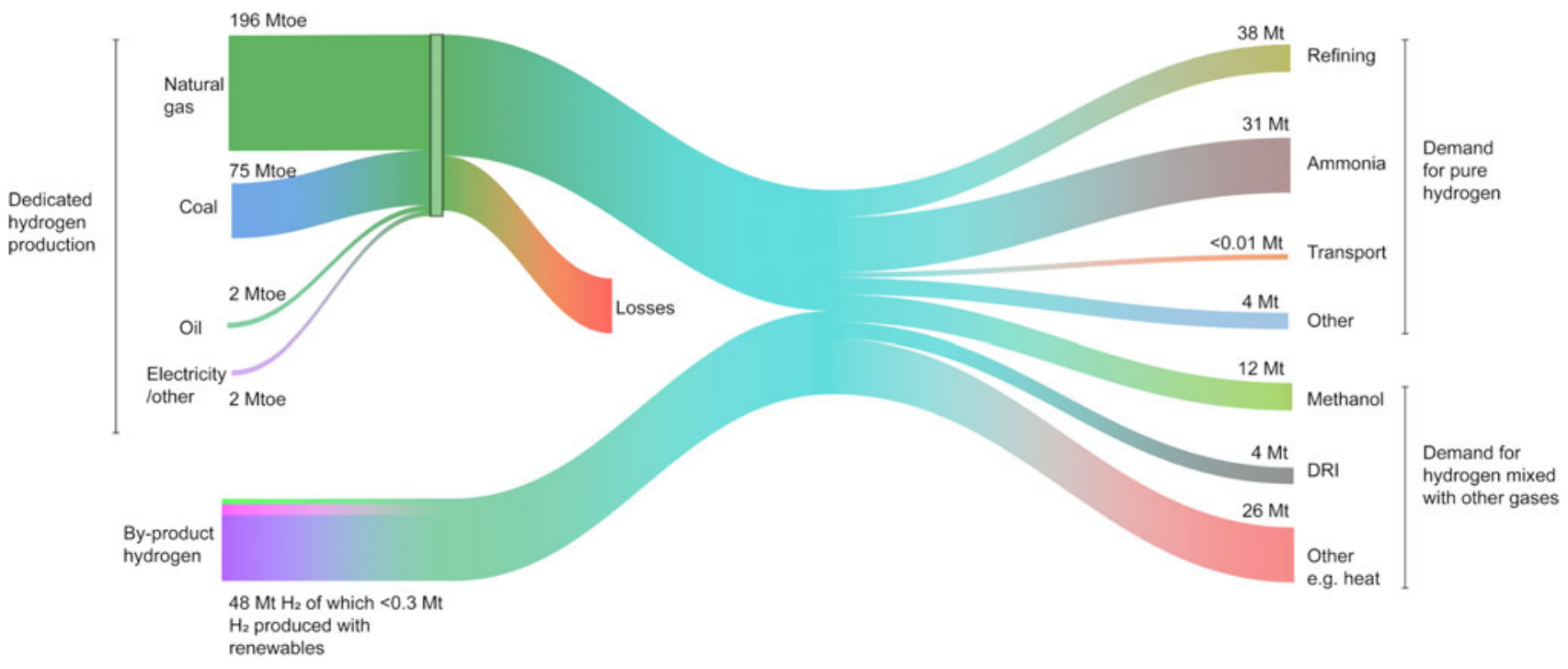

Figure 2. The flow of the global hydrogen production, supply, and demand in 2018 - units in Mt, Mtoe (Million tons of oil equivalent), and DRI (Direct Reduction of Iron). Source: IEA. All rights reserved. ${ }^{1}$ 
At the moment, for all of the mentioned applications, most of the hydrogen is obtained through steam reforming of fossil fuels. In steam reforming, hydrocarbons are converted to carbon monoxide $(\mathrm{CO})$ and $\mathrm{H}_{2}$, commonly known as synthesis gas or syngas, using steam at high temperature $\left(700-1000^{\circ}\right.$ C). ${ }^{11}$

$$
\mathrm{CH}_{4}+\mathrm{H}_{2} \mathrm{O} \leftrightarrow \mathrm{CO}+\mathrm{H}_{2}
$$

However, if hydrogen is to become the fuel of the future, extensive development in advanced technologies for the production of green hydrogen and enabling energy policies are essential to shift our dependence from fossil fuels toward renewables and sustainable hydrogen.

\section{Technologies for renewable hydrogen production}

Hydrogen is often described as a clean and sustainable energy vector but in order to live up to this description, renewable methods using sustainable sources need to be the backbone of hydrogen production. ${ }^{12}$ In this section, renewable methods to produce $\mathrm{H}_{2}$ from water and biomass, along with their associated costs - in USD across the manuscript (Fig. 3), are reviewed in comparison to the production cost of hydrogen from steam methane reforming (1.9-2.6 $\left.\$ / \mathrm{kg} \mathrm{H}_{2}\right)$ and the 2020 U.S. Department of Energy (DOE) target $\left(2 \$ / \mathrm{kg} \mathrm{H}_{2}\right) .{ }^{13,14}$

For a more in-depth analysis, El-Emam and Ozcan published a comprehensive review on the technological, economic, and environmental aspects of renewable hydrogen production. ${ }^{15}$

\section{Making hydrogen from biomass}

Biomass currently covers $14 \%$ of the total primary energy consumption ${ }^{16}$ due to its abundance and ease of accessibility across many countries. ${ }^{17}$ Nowadays, as a $\mathrm{CO}_{2}$ neutral precursor, biomass is considered as an important renewable resource for hydrogen production, ${ }^{18}$ although the carbon foot print associated with the use of biomass for hydrogen production may not be neutral. For example, $8.99 \times 10^{-2} \mathrm{CO}_{2}$ eqv. $\mathrm{g} / \mathrm{s}$ is emitted to produce $0.484 \mathrm{MJ} / \mathrm{s} \mathrm{H}_{2}$ from an annual consumption of $2.53 \times 10^{6} \mathrm{~kg}$ of biomass. ${ }^{19}$ The use of biomass for energy production is often a great concern with respect to land use. However, alternatives likes lignocellulosic waste and crops waste have the potential to address this issue to some extent. ${ }^{20}$ Other types of "low cost" biomass to produce hydrogen include bio-waste, biogas, industrial organic waste, sewage sludge, biooil, and biochar; ${ }^{21-23}$ and the usual hydrogen content in biomass is $\sim 5-7 \mathrm{wt}^{2}$. $^{24}$

Currently, the two main routes to produce hydrogen from biomass are through the thermochemical and biochemical process (Fig. 4). ${ }^{25,26}$ Thermochemical processes include pyrolysis, gasification, steam reforming, and supercritical gasification, ${ }^{21}$ whereas biochemical processes include bio-photolysis, biofermentation, and dark fermentation. ${ }^{27}$ In the biochemical route, biomass can be converted into biofuels through various processes including anaerobic or aerobic digestion, fermentation, and acid hydrolysis. ${ }^{28}$ Recently, emerging technologies like bio-electrochemical systems have also been used to convert waste treatment into energy production. In this method,

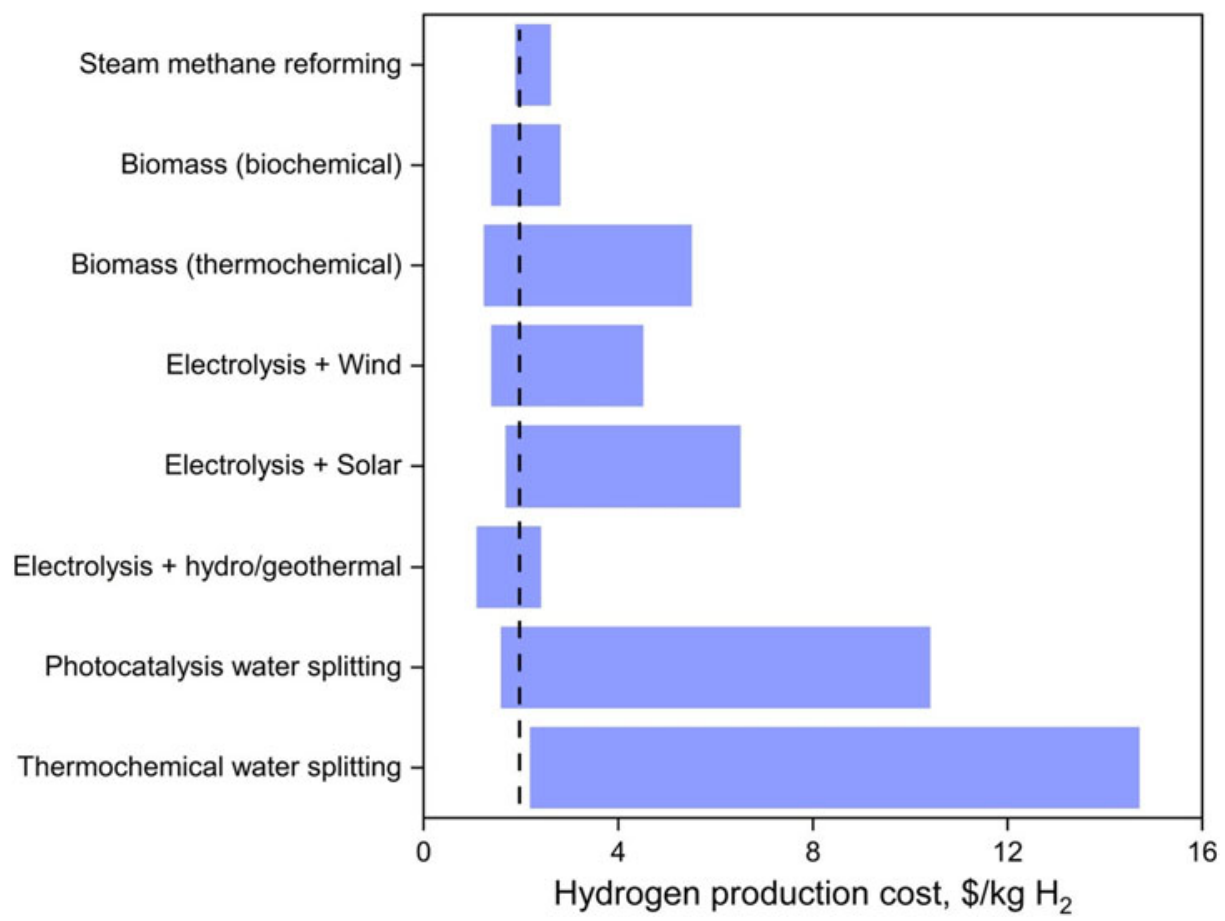

Figure 3. Average hydrogen production cost from various methods. The black dotted line represents the 2020 DOE target of $2 \$ / \mathrm{kg} \mathrm{H}_{2}$. 


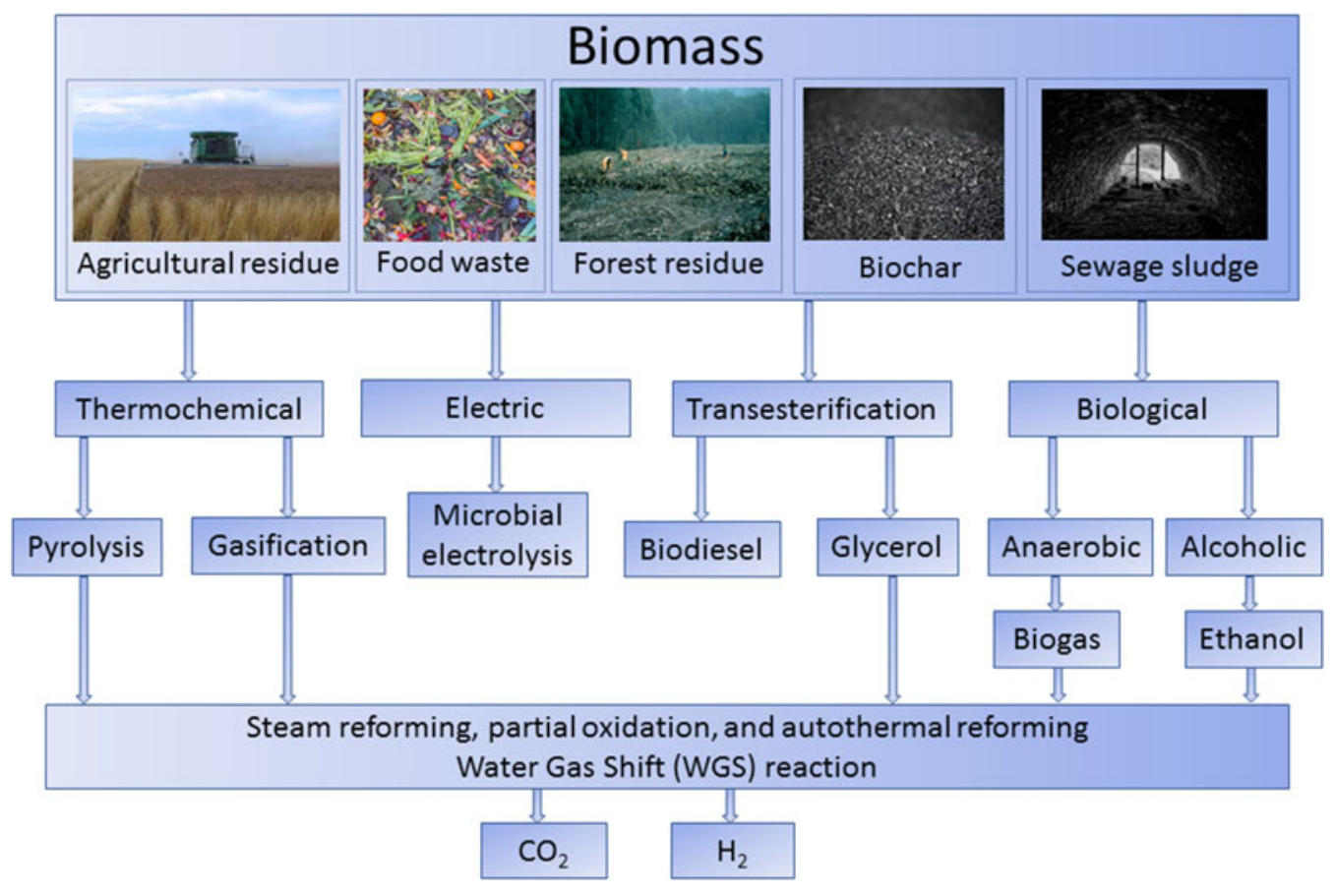

Figure 4. Hydrogen production by different methods from various types of biomass.

electrochemically active micro-organisms (e.g., Shewanella oneidensis and Geobacter sulfurreducens) are grown under electrochemical interactions with electrodes ${ }^{29,30}$ to catalyze and oxidize organic matter to generate $\mathrm{CO}_{2}$, electrons, and protons. ${ }^{30}$ The electrons are transferred to the anode, while the protons move through a membrane to the cathode, where they combine to release $\mathrm{H}_{2} .{ }^{31}$ An example of such system produced $\sim 4.5 \mathrm{l} \mathrm{H}_{2}$ /day from waste water. ${ }^{32}$

Apart from bio-electrochemical systems, hydrogen production from biomass can be light-driven. Light-dependent processes include bio-photolysis and photofermentation. In bio-photolysis, water is split to produce hydrogen by some green algae under anaerobic conditions. Photofermentation is done by using a purple non-sulfur bacteria converting organic acids into $\mathrm{H}_{2}$ and $\mathrm{CO}_{2}$. In light-independent processes, i.e., dark fermentation, organic substrates are converted to $\mathrm{H}_{2}$ in anaerobic condition (Table 1). ${ }^{33}$ With a cost of hydrogen production ranging from 1.4 to $2.8 \$ / \mathrm{kg} \mathrm{H}$, biological routes to process biomass are promising but are currently at a very early experimental stage.

Relative to biological routes, thermochemical methods are more flexible and provide a simpler approach as there is no need for additional chemicals but instead heat and pressure are used to generate biofuels. ${ }^{43}$ This can be done by pyrolysis and/or gasification (Table 2). ${ }^{44,45}$ Gasification is a welldeveloped process where hydrogen-rich fuel gas $\left(\mathrm{CO}, \mathrm{H}_{2}\right.$, and $\left.\mathrm{CH}_{4}\right)$ is produced at $700-1200{ }^{\circ} \mathrm{C}$ using gasification agents $\left(\mathrm{O}_{2}, \mathrm{CO}_{2}\right.$, steam, and air). ${ }^{16,20}$ Gasification with air produces a low-quality gas (4-7 MJ/m $\left.\mathrm{m}^{3} \mathrm{HHV}\right)$, whereas higher quality gas ( 10-18 MJ $\left./ \mathrm{m}^{3} \mathrm{HHV}\right)$ can be obtained under more oxidative conditions, i.e., pure $\mathrm{O}_{2} \cdot{ }^{50}$ The gasification process using fluidized bed reactors have demonstrated high biomass conversion with $\mathrm{H}_{2}$ content in gas $\sim 55$ vol. $\%$ and $\mathrm{H}_{2}$ production of $\sim 6.9$ wt\%. ${ }^{20,51}$ The cost of $\mathrm{H}_{2}$ production by gasification from biomass is estimated to be $\sim 1.77-2.05 \$ / \mathrm{kg} \mathrm{H}_{2},{ }^{14}$ and the process can be generalized in the following equation: ${ }^{52}$

$$
\text { Biomass } \rightarrow \mathrm{H}_{2}+\mathrm{CO}_{2}+\mathrm{CO}+\mathrm{N}_{2}
$$

$\mathrm{H}_{2}$ can also be obtained via the pyrolysis of biomass at lower temperatures of $300-650{ }^{\circ} \mathrm{C},{ }^{20,52,53}$ but, at such temperatures, the hydrogen yield is lowered and of $\sim 18$ vol\%. ${ }^{52}$ However, with suitable catalysts, e.g., $\mathrm{Ni} / \mathrm{Al}_{2} \mathrm{O}_{3},{ }^{20}$ and elevated temperatures, the amount of produced $\mathrm{H}_{2}$ can be increased to yields $\sim 38 \mathrm{vol \%}$ at $600{ }^{\circ} \mathrm{C}$ and $\sim 70$ vol\% at $900{ }^{\circ} \mathrm{C}$. Recently, an effective twostaged pyrolysis process has been proposed, ${ }^{54}$ where the biomass is initially heated to $950{ }^{\circ} \mathrm{C}$ to produce pyrolysis gases, and then further heated at $950{ }^{\circ} \mathrm{C}$ again. With a $10 \mathrm{wt} \%$ Ni-dolomite catalyst, the amount of hydrogen obtained in this two steps process was 59.14 vol\%. ${ }^{55}$ The cost of $\mathrm{H}_{2}$ production from biomass pyrolysis has been calculated as $1.25-2.20 \$ / \mathrm{kg}$ $\mathrm{H}_{2},{ }^{14}$ and the process is generalized in the following equation: ${ }^{52}$

$$
\text { Biomass } \rightarrow \mathrm{H}_{2}+\mathrm{CO}_{2}+\mathrm{CO}+\text { hydrocarbon gases }
$$

Recently, other feedstocks like bioethanol, glycerol, sorbitol, and glucose have also been investigated as a potential source of hydrogen $^{56}$ through the conventional approach of steam 
Table 1. Biological processes to produce hydrogen from biomass.

\begin{tabular}{|c|c|c|c|c|c|c|c|c|}
\hline Process & Reactions & Organisms & Key enzymes & Substrate & $\mathrm{H}_{2}$ yield & $\$ / k g H_{2}$ & Reactors & References \\
\hline Biophotolysis & $\begin{array}{l}\text { Direct: } \\
\quad 2 \mathrm{H}_{2} \mathrm{O}+\text { light } \rightarrow 2 \mathrm{H}_{2}+\mathrm{O}_{2} \\
\quad \text { Indirect: } \\
6 \mathrm{H}_{2} \mathrm{O}+6 \mathrm{CO}_{2}+\text { light } \rightarrow \\
\mathrm{C}_{6} \mathrm{H}_{12} \mathrm{O}_{6}+6 \mathrm{CO}_{2} \\
\mathrm{C}_{6} \mathrm{H}_{12} \mathrm{O}_{6}+2 \mathrm{H}_{2} \mathrm{O} \rightarrow 4 \mathrm{H}_{2} \\
+2 \mathrm{CH}_{3} \mathrm{COOH}+2 \mathrm{CO}_{2}\end{array}$ & $\begin{array}{l}\text { Chlamydomonas reinhardtii, } \\
\text { Chlorella fusca, } \\
\text { Scenedesmus obliquus, } \\
\text { Chlorococcum littorale, } \\
\text { Nostoc, Anabaena, } \\
\text { Calothrix, Oscillatoria }\end{array}$ & $\begin{array}{r}\text { Nitrogenase or } \\
\text { hydrogenase }\end{array}$ & Water, carbohydrate & $\begin{array}{c}119.8 \mathrm{ml} / \mathrm{l} \text { (direct } \\
\text { biophotolysis) }\end{array}$ & $\begin{array}{l}2.13 \text { (direct) } \\
1.42 \\
\text { (indirect) }\end{array}$ & $\begin{array}{l}\text { Photobioreactor, } \\
\text { flat plate } \\
\text { photobioreactor }\end{array}$ & {$[14,33-36]$} \\
\hline Photofermentation & $\begin{array}{l}\mathrm{C}_{6} \mathrm{H}_{12} \mathrm{O}_{6}+6 \mathrm{H}_{2} \mathrm{O}+\text { light } \\
\text { energy } \rightarrow 12 \mathrm{H}_{2}+6 \mathrm{CO}_{2} \\
\text { Nitrogen-deficient } \\
\text { process: } \\
\mathrm{CH}_{3} \mathrm{COOH}+2 \mathrm{H}_{2} \mathrm{O}+ \\
\text { light energy } \rightarrow 2 \mathrm{H}_{2}+ \\
2 \mathrm{CO}_{2}\end{array}$ & $\begin{array}{l}\text { Rhodobacter capsulatus, } \\
\text { Rhodobium marinum, } R \text {. } \\
\text { sphaeroides }\end{array}$ & $\begin{array}{l}\text { Nitrogenase, } \\
\text { hydrogenase }\end{array}$ & $\begin{array}{l}\text { Sugar beet } \\
\text { molasses, food } \\
\text { waste, } \\
\text { wastewater }\end{array}$ & $\begin{array}{l}1 \mathrm{l} / / \mathrm{l} \text { with } 28 \mathrm{~g} / \mathrm{l} \\
\text { sugar-containing } \\
\text { culture, } 3.65 \mathrm{~mol} / \\
\text { mol mixed acids } \\
\text { (acid and butyric } \\
\text { acid) }\end{array}$ & 2.83 & $\begin{array}{l}\text { Borosilicate glass } \\
\text { bioreactors, fed } \\
\text { batch }\end{array}$ & $\begin{array}{c}{[14,35,37-} \\
39]\end{array}$ \\
\hline Dark fermentation & $\begin{array}{l}\mathrm{C}_{6} \mathrm{H}_{12} \mathrm{O}_{6}+6 \mathrm{H}_{2} \mathrm{O} \rightarrow 12 \mathrm{H}_{2}+ \\
\quad 6 \mathrm{CO}_{2}\end{array}$ & $\begin{array}{l}\text { Bacillus, Enterobacter, } \\
\text { Clostridium, Thermotoga, } \\
\text { Thermoanaerobacterium }\end{array}$ & Hydrogenase & $\begin{array}{l}\text { Wastewater mixed } \\
\text { sludge, glucose, } \\
\text { xylose }\end{array}$ & $\begin{array}{l}\sim 1.7 \mathrm{~mol} / \mathrm{mol} \\
\text { glucose, } 0.8 \mathrm{~mol} / \\
\text { mol xylose }\end{array}$ & 2.57 & $\begin{array}{l}\text { Gass bioreactors } \\
\text { serum bottles, } \\
\text { fluidized bed } \\
\text { reactors }\end{array}$ & {$[14,40-42]$} \\
\hline
\end{tabular}


Table 2. Hydrogen production strategies from pyrolysis and the gasification process.

\begin{tabular}{|c|c|c|c|c|c|}
\hline Methods & Brief description & $\begin{array}{l}\text { Reactor and } \\
\text { condition }\end{array}$ & Advantage & Disadvantage & Product yield \\
\hline Air gasification 21,24,46 & $\begin{array}{l}\text { Uses air as a gasifying } \\
\text { agent to produce } \mathrm{CO}+\mathrm{H}_{2}\end{array}$ & $\begin{array}{l}\text { Fluidized bed } \\
\text { reactor } / 700- \\
900{ }^{\circ} \mathrm{C} \text { air with } \\
\text { steam mixture }\end{array}$ & $\begin{array}{c}\text { Can achieve } \\
\text { maximum } \\
\text { conversion }\end{array}$ & $\begin{array}{l}\text { Removal of tar from } \\
\text { the product is } \\
\text { difficult }\end{array}$ & $\begin{array}{r}\text { High } \mathrm{H}_{2} \text { and gas yield } \\
\text { at high temperature }\end{array}$ \\
\hline $\begin{array}{l}\text { Steam } \\
\quad \text { gasification } 21,24,26,47\end{array}$ & $\begin{array}{c}\text { Uses steam along with air } \\
\text { to produce } \mathrm{H}_{2} \text {-rich syngas }\end{array}$ & $\begin{array}{l}\text { Fluidized bed } \\
\text { gasifier } / 770{ }^{\circ} \mathrm{C} \\
\text { and steam to the } \\
\text { biomass ratio of } \\
1\end{array}$ & $\begin{array}{l}\text { High } \mathrm{H}_{2} \text { to } \mathrm{CO} \\
\text { ratio, suitable } \\
\text { for large-scale } \\
\text { industrial } \\
\text { production }\end{array}$ & $\begin{array}{l}\text { High tar content and } \\
\mathrm{CO}_{2} \text { emission }\end{array}$ & $19.4-42.6 \% \mathrm{H}_{2}$ \\
\hline 0xygen gasification ${ }^{24}$ & $\begin{array}{r}\text { Supplies pure oxygen into } \\
\text { gasifier for gasification }\end{array}$ & $\begin{array}{l}\text { Circulating } \\
\text { fluidized bed } \\
\text { gasifier }\end{array}$ & $\begin{array}{l}\text { Low tar content in } \\
\text { the syngas } \\
\text { produced }\end{array}$ & $\begin{array}{l}\text { Purifying oxygen is an } \\
\text { energy-intensive } \\
\text { process }\end{array}$ & \\
\hline $\begin{array}{l}\text { Supercritical water } \\
\text { gasification } 21,24,26,48\end{array}$ & $\begin{array}{l}\text { Uses supercritical steam as } \\
\text { a gasifying agent. Also, } \\
\text { at the supercritical } \\
\text { condition, steam works } \\
\text { as a catalyst toward the } \\
\text { conversion }\end{array}$ & $\begin{array}{l}\text { Tubular batch } \\
\text { reactor } 650^{\circ} \mathrm{C} \\
\text { with a heating } \\
\text { range of } 30^{\circ} \mathrm{C} / \\
\text { min }\end{array}$ & $\begin{array}{l}\text { High conversion } \\
\text { and } \mathrm{H}_{2} \text { content } \\
\text { without tar and } \\
\text { coke formation }\end{array}$ & $\begin{array}{l}\text { High energy input to } \\
\text { pump the feed } \\
\text { stock, strict } \\
\text { operating } \\
\text { condition, and } \\
\text { difficult to recycle } \\
\text { alkaline catalyst }\end{array}$ & $30-40 \% \mathrm{H}_{2}$ \\
\hline Fast pyrolysis ${ }^{21,24,26,49}$ & $\begin{array}{l}\text { 0ccurs at moderate } \\
\text { temperature in the } \\
\text { absence of oxygen with a } \\
\text { high heat transfer rate to } \\
\text { the biomass particle }\end{array}$ & $\begin{array}{l}\text { Fluidized bed } \\
\text { reactor, } \\
\text { atmospheric } \\
\text { pressure }\end{array}$ & $\begin{array}{l}\text { Can produce high } \\
\text { hydrogen } \\
\text { content gas }\end{array}$ & $\begin{array}{c}\text { Low hydrogen yield } \\
\text { and high energy } \\
\text { consumption }\end{array}$ & $\begin{array}{l}12 \% \text { gases ( } 2-3 \text { wt } \% \\
\text { of } \mathrm{H}_{2} \text { to biomass), } \\
72 \% \text { bio-oil, } 16 \% \\
\text { char }\end{array}$ \\
\hline
\end{tabular}

reforming $^{11}$ :

$$
\mathrm{C}_{n} \mathrm{H}_{m}+n \mathrm{H}_{2} \mathrm{O} \leftrightarrow n \mathrm{CO}+\left(\frac{m}{2}+n\right) \mathrm{H}_{2}
$$

In this approach, the hydrogen content in syngas varies according to the gasification operating conditions, i.e. temperature, steam-to-biomass ratio, and catalysts. Steam gasification is prone to the formation of tar, which may affect the maintenance and operation cost due to pipeline blockage. ${ }^{57}$ Therefore, catalysts are often used to promote tar cracking and reduce the operating temperature as well as increase the hydrogen selectivity from biomass. ${ }^{58}$ Some of the common catalysts are alkaline earth catalysts (e.g., $\mathrm{KOH}, \mathrm{KHCO}_{3}, \mathrm{Na}_{3} \mathrm{PO}_{4}$, $\mathrm{MgO}$, and $\mathrm{NaOH}$ ), ${ }^{26,59}$ metal-based catalysts (e.g., $\mathrm{Ni} / \mathrm{Al}_{2} \mathrm{O}_{3}$. $\mathrm{Ni} / \mathrm{Al}, \mathrm{Ni} / \mathrm{Zn} / \mathrm{Al}, \mathrm{Cu} / \mathrm{Zn} / \mathrm{Zr}, \mathrm{Rh} / \mathrm{Zr} / \mathrm{Ce}, \mathrm{Pt} / \mathrm{Co} / \mathrm{CeO}_{2}$, and $\mathrm{Ru} / \mathrm{SrO}-\mathrm{Al}_{2} \mathrm{O}_{3}$ ), ${ }^{60-67}$ and mineral catalysts (dolomite and olivine). ${ }^{68,69}$ The activity of the metal-based catalysts supported on $\mathrm{Al}_{2} \mathrm{O}_{3}-\mathrm{MgO}$ is in an order of $\mathrm{Ru}>\mathrm{Rh}>\mathrm{Ir}>\mathrm{Ni}>\mathrm{Pt}^{70}$ Although the noble metals such as $\mathrm{Ru}$ and Rh can effectively promote gasification, these remain expensive. Traditional alkali metal catalysts have also been used effectively; however, challenges remain due to the high loading, easy scaling, blockage, and difficult recovery. As a result, Ni-based catalysts have been widely used especially due to their synergy with other metals.

For example, $100 \%$ carbon conversion and $\sim 70$ vol\% $\mathrm{H}_{2}$ yield have been reported with a $\mathrm{Pt}-\mathrm{Ni} / \mathrm{CeO}_{2}-\mathrm{SiO}_{2}$ catalyst. ${ }^{71}$ With an estimated cost of $\mathrm{H}_{2}$ production up to $\sim 5.5 \$ / \mathrm{kg} \mathrm{H}_{2},{ }^{72}$ more scientific advancement is needed before biomass gasification technologies can be used at an industrial scale. The future efforts are expected to be on tar treatment, cost-effective catalysts, condition optimization, and large-scale implementation.

\section{Making hydrogen by splitting water}

Even though water is an abundant hydrogen source, water electrolysis accounts for only a small fraction of the global hydrogen production. ${ }^{73}$ Depending on the energy source used, water electrolysis can be a completely sustainable and a clean way to generate hydrogen since no greenhouse gas is 
emitted. ${ }^{74}$ Hydrogen production from water splitting can be done by using various methods including electrolysis and photocatalysis. ${ }^{75}$ However, the latter is far from mature. During the photocatalysis process, a light excited semiconducting electrode with a suitable excitation bandgap, e.g., $\mathrm{TiO}_{2}$, is used to split water into hydrogen and oxygen. ${ }^{76}$ Unfortunately, $\mathrm{TiO}_{2}$ strongly absorbs light in the UV spectrum $(\lambda<350 \mathrm{~nm})$ only, and not in the visible light range $(350 \mathrm{~nm}<\lambda<700 \mathrm{~nm})$, and this results in a poor photocatalytic activity under sunlight. The development of high-performing photocatalysts under sunlight is therefore critical for photocatalysis to become a key method to produce $\mathrm{H}_{2}^{77}$. To date, many semiconductor photocatalysts and co-catalysts have been studied including doped $\mathrm{TiO}_{2},{ }^{78}$ perovskites, ${ }^{79}$ graphitic $\mathrm{C}_{3} \mathrm{~N}_{4},{ }^{80} \mathrm{BiVO}_{4},{ }^{81}$ and $\mathrm{NiS} .{ }^{82}$ Although this approach is reported to have less environmental impact, the poor efficiency $(10-18 \%)^{83}$ and relative high cost are not attractive. ${ }^{84}$ Early estimation would suggest a hydrogen production cost between 1.6 and $10.4 \$ / \mathrm{kg} \mathrm{H}_{2}{ }^{85}$

Exotic methods including sonolysis, where a sound wave between 20 and $40 \mathrm{kHz}$ is used to split water through cavitation effects, have been reported. ${ }^{86}$ Thermochemical water splitting from solar concentrators $\left(>2000{ }^{\circ} \mathrm{C}\right)$ have also been proposed with relatively high efficiency $(49 \%$ solar-to-fuel energy conversion efficiency). ${ }^{87}$ Depending on the type of thermochemical cycles used (where heat sources and chemical reactions are combined to split water into hydrogen and oxygen), ${ }^{75}$ the cost of $\mathrm{H}_{2}$ production varies considerably from $2.8-4.1 \$ / \mathrm{kg} \mathrm{H}_{2}$ for the hybrid sulfur cycle, ${ }^{88}$ to $8.0-14.7 \$ / \mathrm{kg} \mathrm{H}_{2}$ for the $\mathrm{ZnO} / \mathrm{Zn}$ cycle, ${ }^{89}$ and $2.2 \$ / \mathrm{kg} \mathrm{H}_{2}$ for the $\mathrm{Cu}-\mathrm{Cl}$ cycle. ${ }^{75}$

Electrolysis is a general term describing the process of driving a non-spontaneous electrochemical reaction by applying a voltage difference between two electrodes. In water electrolysis, gaseous hydrogen and oxygen are generated from water in the following equation:

$$
2 \mathrm{H}_{2} \mathrm{O}(\mathrm{l}) \rightarrow 2 \mathrm{H}_{2}(\mathrm{~g})+\mathrm{O}_{2}(\mathrm{~g})
$$

This is an energy-demanding reaction with a change in Gibbs free energy of $237.2 \mathrm{~kJ} / \mathrm{mol}$ at standard conditions. ${ }^{90,91}$ If this reaction is done in an electrochemical cell, a potential difference of $1.23 \mathrm{~V}$ is required at room temperature and standard pressure. $^{92}$ Various electrochemical cell configurations and chemistry have been investigated to generate hydrogen through water electrolysis. These technologies are at various stages of maturity and include the proton exchange membrane (PEM), ${ }^{93,94}$ alkaline water (AW), ${ }^{95,96}$ anion exchange membrane (AEM), ${ }^{97,98}$ solid oxide electrolysis (SOE), ${ }^{99}$ and microbial electrolysis cell (MEC) ${ }^{100}$ technologies.

Table 3 summarizes the characteristics of these different approaches, and to date, AW electrolysis remains the most cost effective approach to generate hydrogen. ${ }^{104-106}$ PEM systems lead to the highest $\mathrm{H}_{2}$ purity but unfortunately suffer from several limitations such as electrolyte contamination, ${ }^{107,108}$ and deterioration, ${ }^{109}$ and slow oxygen evolution reaction (OER) kinetics. ${ }^{110}$ To speed up the OER kinetics, various catalysts have been tested including Pt on carbon, ruthenium-based materials, ${ }^{111}$ and non-noble metal catalysts ${ }^{112}$

The price and source of electricity to power the electrolysis reaction are additional factors to consider. Several projects have demonstrated the technological viability of renewable hydrogen from wind and solar. However, advancements in direct and more efficient water electrolysis processes from renewable sources are needed to reduce cost and facilitate the uptake of renewable hydrogen. ${ }^{113}$

Over the past decades, there has been a rapid increase in installed capacity of wind energy coupled with a decrease in the associated costs. ${ }^{114}$ It is therefore of little surprise that researchers around the planet are looking into the utilization of wind energy to produce hydrogen. ${ }^{115-118}$ The calculated costs involved with $\mathrm{H}_{2}$ production from wind energy vary widely based on several factors including if the wind-mills are gridconnected or isolated systems, the type of electrolysers used, and wind penetration scenarios. ${ }^{119}$ For example, a Norwegian study calculated prices between 2.0 and $4.5 \$ / \mathrm{kg} \mathrm{H}_{2},{ }^{115} \mathrm{a}$ Danish study predicted a price of around $3.5 \$ / \mathrm{kg} \mathrm{H}_{2},{ }^{119}$ whereas a South African study listed values between 1.4 and $39.5 \$ / \mathrm{kg} \mathrm{H}_{2} .{ }^{116}$ The annual hydrogen production volume also varies considerably based on the country's available wind energy capacity and the mean wind speed. In Fayzabad, Afghanistan, a $100 \mathrm{~kW}$ wind turbine system could produce up to $8.7 \times 10^{6} \mathrm{~kg} \mathrm{H}_{2}$ /year, ${ }^{117}$ in South Africa, between $6.5 \times 10^{3}$ and $2.3 \times 10^{5} \mathrm{~kg} \mathrm{H}_{2}$ /year could be generated, ${ }^{116}$ while in Brazil the projected hydrogen production from the surplus wind electricity was predicted to be of $2.2 \times 10^{11} \mathrm{~kg} \mathrm{H}_{2}$ /year. ${ }^{118}$

Producing hydrogen from photovoltaics (PV) was once the most expensive method (up to $78.6 \$ / \mathrm{kg} \mathrm{H}_{2}$ ) due to the high cost of the PV system. ${ }^{120}$ However, installed solar capacity has increased drastically due to the recent sharp drop in price of solar PV systems. ${ }^{121}$ To date, solar is the most cost-competitive way to produce clean renewable hydrogen. ${ }^{122}$ In 2007 , a study calculated that a PV electrolysis plant of $260 \mathrm{~km}^{2}$ would be enough to provide an annual $\mathrm{H}_{2}$ production of $2.2 \times 10^{8} \mathrm{~kg}$ at a cost of $6.5 \$ / \mathrm{kg} \mathrm{H}_{2},{ }^{123}$ and since then, the cost of solar hydrogen has fallen to less than $3 \$ / \mathrm{kg} \mathrm{H}_{2} \cdot{ }^{124}$ Solar hydrogen production capacity and the cost of course depend on multiple factors including the country and location (solar irradiation level), the type of electrolysers, and the nature of the PV systems, i.e., gridconnected or autonomous. ${ }^{122}$ For example, it has been predicted that a $20 \mathrm{~kW} \mathrm{PV} \mathrm{system} \mathrm{receiving} 299 \mathrm{MW} / \mathrm{h}$ of solar radiation would produce $3.73 \times 10^{5} \mathrm{~kg} \mathrm{H}_{2} /$ year, ${ }^{125}$ while a Japanese study projected a low production cost of 1.7-2.8 \$/ kg using a PV and battery-assisted electrolysers. ${ }^{124}$ As compared with solar, wind energy has the advantage of being a "dual-use" technology where the land can still be used for other important activities such as farming and agriculture, or even solar farms. Hybrid wind-solar systems could be one solution in order to maximize the use of land and minimize the problem of intermittent solar irradiation. ${ }^{126-128}$ Floating systems could also provide alternatives to produce hydrogen while minimizing land impact. $^{129}$ 
Table 3. Materials, components, and characteristics of different electrolysis systems.

\begin{tabular}{|c|c|c|c|}
\hline & Alkaline $e^{101,102}$ & PEM ${ }^{101,102}$ & AEM 101,103 \\
\hline Electrolyte & $20-30 \% \mathrm{KOH}$ & PFSA & QAPS \\
\hline Charge carrier & $\mathrm{OH}^{-}$ & $\mathrm{H}^{+}$ & $\mathrm{OH}^{-}$ \\
\hline Temperature range $\left({ }^{\circ} \mathrm{C}\right)$ & $65-100$ & $70-100$ & $50-70$ \\
\hline $\begin{array}{l}\text { Typical discharge } \mathrm{H}_{2} \text { pressure } \\
\text { (bar) }\end{array}$ & $25-30$ & $30-80$ & 30 \\
\hline Separator & $\begin{array}{l}\text { Asbestos, PAMa, } \mathrm{ZrO}_{2}-\mathrm{PPS}, \mathrm{NiO} \\
\mathrm{Sb}_{2} \mathrm{O}_{5} \text {-PS }\end{array}$ & PFSA (e.g., Nafion) & QAPS (e.g., A-201) \\
\hline OER catalyst & $\mathrm{Ni}_{2} \mathrm{COO}_{4}, \mathrm{La}-\mathrm{Sr}-\mathrm{COO}_{3}, \mathrm{CO}_{3} \mathrm{O}_{4}$ & Ir/Ru oxide & $\mathrm{CO}_{3} \mathrm{O}_{4}$ \\
\hline HER catalyst & $\mathrm{Ni}$ & Pt & $\mathrm{CeO}_{2}-\mathrm{La}_{2} \mathrm{O}_{3}$ \\
\hline Typical current collector & $\mathrm{Ni}$ & Titanium & $\mathrm{Ni}$ \\
\hline Cell sealant & Metallic & $\begin{array}{l}\text { Synthetic rubber or } \\
\text { fluoroelastomer }\end{array}$ & $\begin{array}{l}\text { Synthetic rubber or } \\
\text { fluoroelastomer }\end{array}$ \\
\hline Anodic reaction & $2 \mathrm{OH}^{-} \rightarrow \mathrm{H}_{2} \mathrm{O}+1 / 2 \mathrm{O}_{2}+\mathrm{e}^{-}$ & $2 \mathrm{H}_{2} \mathrm{O} \rightarrow \mathrm{O}_{2}+4 \mathrm{H}^{+}+4 \mathrm{e}^{-}$ & $2 \mathrm{OH}^{-} \rightarrow \mathrm{H}_{2} \mathrm{O}+1 / 2 \mathrm{O}_{2}+\mathrm{e}^{-}$ \\
\hline Cathodic reaction & $2 \mathrm{H}_{2} \mathrm{O}+2 \mathrm{e}^{-} \rightarrow 2 \mathrm{H}_{2}+2 \mathrm{OH}^{-}$ & $4 \mathrm{H}^{+}+4 \mathrm{e}^{-} \rightarrow 4 \mathrm{H}_{2}$ & $2 \mathrm{H}_{2} \mathrm{O}+2 \mathrm{e}^{-} \rightarrow 2 \mathrm{H}_{2}+2 \mathrm{OH}^{-}$ \\
\hline $\begin{array}{l}\text { Conventional current density (mA/ } \\
\mathrm{cm}^{2} \text { ) }\end{array}$ & $200-500$ & $800-2500$ & $200-500$ \\
\hline Demonstrated durability (h) & 100,000 & $100,000-50,000$ & NA \\
\hline Hydrogen purity (\%) & $99.3-99.9$ & 99.9999 & 99.99 \\
\hline Typical current efficiency & $50-70.8$ & $48.5-65.5$ & 39.7 \\
\hline $\begin{array}{l}\text { Demonstrated rated production } \\
\left(\mathrm{N} \mathrm{m}^{3} / \mathrm{h}\right)\end{array}$ & $1-760$ & $0.265-30$ & $0.25-1$ \\
\hline $\begin{array}{l}\text { Specific energy consumption } \\
\left(\mathrm{kWh} \mathrm{N} / \mathrm{m}^{3}\right)\end{array}$ & $4.5-7.5$ & $5.8-7.3$ & $5.2-4.8$ \\
\hline Demonstrated rated power (kW) & $2.8-3534$ & $1.8-174$ & $1.3-4.8$ \\
\hline System cost ( $\$ / k g)$ & $1400-900$ & $2200-1300$ & NA \\
\hline Technology status & Mature for large scale & Mature for small scale & $R \& D$ \\
\hline
\end{tabular}

PAMa: polysulphone-bonded polyantimonic acid; $\mathrm{PPS}: \mathrm{ZrO}_{2}$ on polyphenylsulphone; $\mathrm{Sb}_{2} \mathrm{O}_{5}$-PS: polysulphone impregnated with $\mathrm{Sb}_{2} \mathrm{O}_{5}$ polyoxide; $\mathrm{PFSA}$ perflurosulfonated acid; QAPS: quaternary ammonia polysulfone; OER: oxygen evolution reaction; HER: hydrogen evolution reaction; NA: not available.

Alternatives including hydropower and geothermal may also have the potential to be used to produce hydrogen. Hydropower is often considered expensive due to the upfront capital cost of building huge dams. However, a Canadian study found that despite the initial capital costs, hydropower $\mathrm{H}_{2}$ production is cost competitive as compared with steam methane reforming 
at $2.4 \$ / \mathrm{kg} \mathrm{H}_{2}$, and if the upfront investments are excluded (by using existing hydropower plants), the hydrogen cost goes down to $1.2 \$ / \mathrm{kg} \mathrm{H}_{2} \cdot{ }^{130}$ Geothermal energy is another source of sustainable energy, and a recent study demonstrated that geothermal powered electrolysis is a viable method for hydrogen production $\left(1.1 \$ / \mathrm{kg} \mathrm{H}_{2}\right)$ with a payback period of only 4-5 years. $^{131}$

\section{Storage and distribution of hydrogen}

Effective methods to store hydrogen are essential to enable its widespread utilization in particular for industrial use where plants require a constant feedstock input. The main problem with storing hydrogen is its low volumetric density. Hydrogen is the lightest element, and at ambient condition, it is a gas with a low density of $0.0899 \mathrm{~kg} / \mathrm{m}^{3} .{ }^{132}$ Even when liquefied at $-253{ }^{\circ} \mathrm{C}$, the density of $\mathrm{H}_{2}$ is only $70.8 \mathrm{~kg} / \mathrm{m}^{3}$, which is onefifteenth of water's density. Hydrogen is also a very small highly diffusive molecule and thus hydrogen leaks can easily occur. ${ }^{133}$ Besides, the use of hydrogen is associated with difficulties in terms of materials' compatibility. In particular, the dissociation of hydrogen molecules at the surface of metals and further hydrogen diffusion at metallic interstitial sites can lead to piping embrittlement and accidental fracture as a result of the reduced ductility and weakening of metals subjected to high purity/pressure hydrogen. ${ }^{134-136}$ The storage of hydrogen is also more delicate than other fuels, because hydrogen has higher laminar burning, buoyant, and propagation velocities that results in higher flammability than other fuels. In addition, hydrogen is also very sensitive to detonation due to its wide volume fraction range of ignition (4-74\%) and detonation $(18-59 \%) .{ }^{137-140}$
Existing methods to store hydrogen are summarized in Fig. 5. Storing hydrogen in high pressure vessels (up to 700 bar in lightweight composite cylinder) is the most common method so far, but the resulting low volumetric storage density, high cost of the composite vessels $(\sim \$ 13 / \mathrm{KWh}$ for 100,000 vessels per year), ${ }^{141}$ and their maintenance/safety are still a concern. $^{140}$ Cryogenic tanks are designed to store liquid hydrogen at $-253{ }^{\circ} \mathrm{C}$ under ambient pressure (the pressure can increase to $10^{4}$ bar in a closed storage system due to the low critical temperature $\left(-239.95^{\circ} \mathrm{C}\right)$ of hydrogen $) .{ }^{142}$ As a general observation and depending on the vessel design, conventional cryogenic tanks can store twice more hydrogen per volume as compared to 700 bar hydrogen gas tanks. ${ }^{142}$ However, with such a storage technology, it is inevitable to avoid the loss of hydrogen even with a perfect insulation because of heat leakage. ${ }^{143,144}$ The boiling losses of $0.4 \%$ per day for a $50 \mathrm{~m}^{3}$ double-walled vacuum-insulated spherical Dewar vessel have been reported. ${ }^{145}$ In addition, hydrogen liquefaction is a very energy intensive process with at least $30 \%$ of the energy stored lost through the liquefaction of hydrogen. ${ }^{146}$

Hydrogen can also be stored by materials physically or chemically. This includes microporous materials, interstitial metal hydrides, and complex hydrides. Microporous materials, including carbon materials, ${ }^{147-152}$ zeolites, ${ }^{153-158}$ and metal organic frameworks (MOFs), ${ }^{159-163}$ can absorb molecular hydrogen in their porous structures at low temperature. ${ }^{152,164,165}$ The hydrogen storage capacity then depends upon the specific surface areas and the applied pressure. ${ }^{142,152}$ Typically, the adsorption capacity of MOFs is $<2 \mathrm{wt} \%$ at room temperature. ${ }^{166}$ The advantage of porous materials is that they allow for hydrogen storage at higher temperatures, e.g., $-150{ }^{\circ} \mathrm{C}$, than feasible with cryogenic tanks for the similar volumetric hydrogen densities. $^{143}$

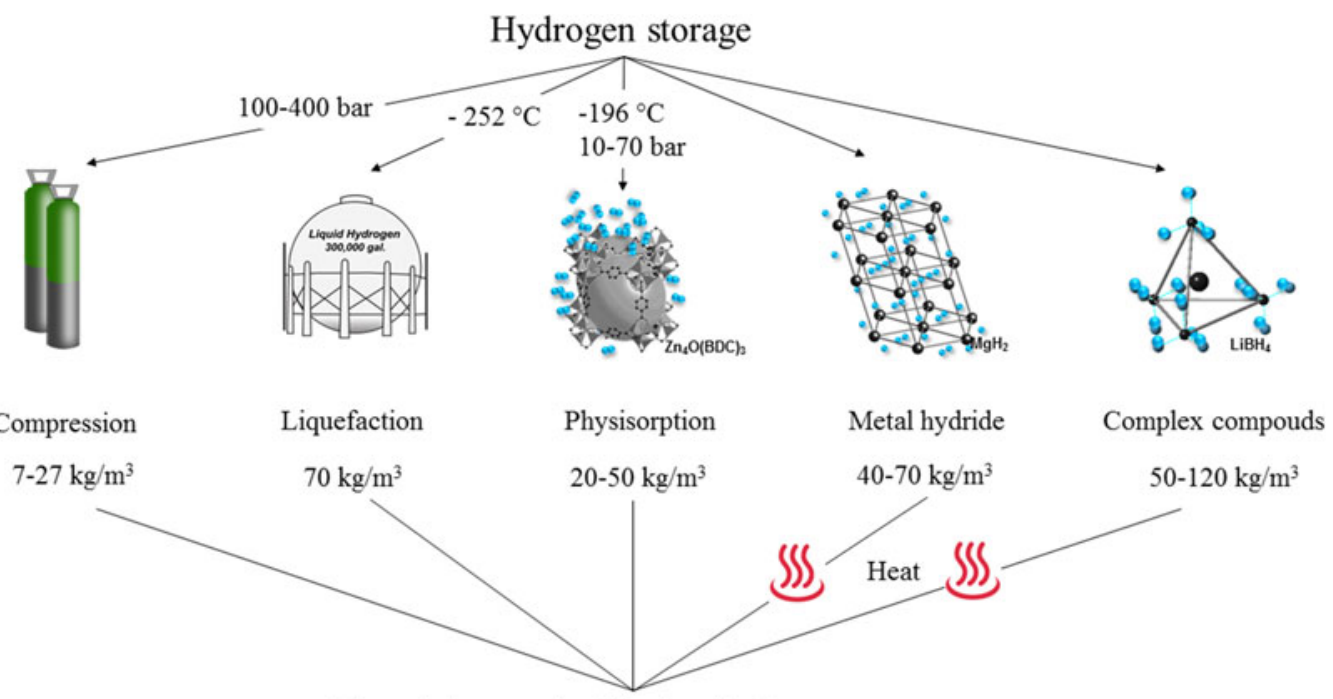

Electricity steel mill chemical processes

Figure 5. Hydrogen storage methods with their respective volumetric densities. 
An alternative method to store hydrogen is in the use of materials storing hydrogen within their structure to form a hydride. Metal hydrides are usually formed by the reaction between metals or intermetallic compounds with hydrogen by the reversible reaction below ${ }^{167}$ :

$$
\mathrm{M}_{(\mathrm{s})}+x / 2 H_{2(\mathrm{~g})} \leftrightarrow \mathrm{MH}_{(\mathrm{S})}+\mathrm{Q}
$$

where $\mathrm{M}$ is either a metal, an alloy, or an intermetallic compound, $\mathrm{MH}$ is the metal hydride formed, and Q is the heat generated during the reaction. ${ }^{167}$

Interstitial metal hydrides are capable of absorbing large amounts of hydrogen (i.e., the volumetric density of $\mathrm{LaNi}_{5}$ is $123 \mathrm{~kg} \mathrm{H} / \mathrm{m}^{3}$ of material; that is 1.74 times more than that of liquid hydrogen). In this process, hydrogen is stored in an atomic form after dissociation of molecular hydrogen at the surface of the interstitial metal. ${ }^{147}$

Generally, existing binary hydrides along the periodic table of elements are too unstable or too stable to be relevant for practical application. However, it has been found that intermetallic compounds, e.g., TiFe, $\mathrm{ZrV}_{2}$, and $\mathrm{LaNi}_{5},{ }^{166,168,169}$ formed by alloying at least two elements (one unstable with one stable hydride) can facilitate the hydrogen storage properties. Generally, the element forming a stable hydride are transition metals or rare earths like Ti, Zr, Y, and La. The unstable hydride elements (often absorbing hydrogen at high hydrogen pressure only) are transition metals including $\mathrm{Cr}, \mathrm{Mn}, \mathrm{Fe}, \mathrm{Co}$, and $\mathrm{Ni}$. The formation of intermetallic alloyed by these two elements can lead to intermediate hydrogen sorption properties with reversibility. Interstitial metal hydrides show excellent and practical hydrogen storage properties since they can uptake and release a large amount of hydrogen safely at ambient temperature and moderate hydrogen pressures. ${ }^{170}$ However, one of the major limitations of these interstitial hydrides is their weight, because their composition involves heavy elements, and this results in low gravimetric hydrogen storage capacities.

Better hydrogen storage materials, i.e., of higher gravimetric storage capacities, may exist in the form of complex hydrides. Complex hydrides are ionic compounds that release hydrogen when they decompose. ${ }^{170}$ Complex hydrides are usually formed through the combination of alkali or alkaline earth metals, e.g., $\mathrm{Li}, \mathrm{Na}$ and $\mathrm{Mg}$, and $\left[\mathrm{AlH}_{4}\right]^{-},\left[\mathrm{NH}_{2}\right]^{-}$, and $\left[\mathrm{BH}_{4}\right]^{-}$groups. The theoretical gravimetric and volumetric densities of some of the complex hydrides are high, for example, the theoretical gravimetric capacity of $\mathrm{LiBH}_{4}$ is $18.5 \%$ and the volumetric capacity is $121 \mathrm{~kg} \mathrm{H}_{2} / \mathrm{m}^{3}$ (70\% more than the volumetric capacity of liquid hydrogen). ${ }^{171-173}$ However, the multiple steps of hydrogen desorption, the release of impurities in the form of $\mathrm{B}_{2} \mathrm{H}_{6}$ from borohydrides or $\mathrm{NH}_{3}$ from amides, and the poor hydrogen reversibility of these materials remain the main barrier for their practical applications. The poor reversibility is generally due to the formation of stable intermediate decomposition products during decomposition and extensive elemental disproportion. ${ }^{166}$ Different strategies including those based on the potential to alter the properties of hydrogen in nano- hydride materials are under current investigations to tackle these challenges. ${ }^{166}$

Currently, hydrogen is delivered from production sites to the end-users including refueling stations by road or pipeline depending on the application, volume, and distance. ${ }^{174}$ For small volumes, transport by road remains the most favorable option. In this case, hydrogen is compressed to 180-200 bar and delivered by tube trailers. Delivering liquid hydrogen is more economical over long distances due to the higher volumetric density. A 40 ton truck can carry $350 \mathrm{~kg}$ of gaseous hydrogen or $3500 \mathrm{~kg}$ liquid hydrogen, ${ }^{143}$ and the delivery cost of compressed hydrogen gas is $\$ 1 / \mathrm{kg} / 100 \mathrm{~km}$ by tube trailers and $\$ 0.1 / \mathrm{kg} / 100 \mathrm{~km}$ for liquid hydrogen by trucks in the USA. ${ }^{175}$ Hydrogen is also noncorrosive; therefore, this facilitates the design and construction of tank trailers. However, because of the extreme low temperature, additional space for safety and suitable thermal insulation must be considered. ${ }^{138,143}$

Gaseous hydrogen can also be transported in pipelines like natural gas, especially when large volumes are to be transported over long distances. In this case, the cost of hydrogen transport is estimated to be of $\$ 0.1 / \mathrm{kg} \mathrm{H}$ over $100 \mathrm{~km}$. ${ }^{138}$ However, this does not take into account the need to retrofit exiting gas network. Conventional pipelines for natural gas are made of steel with a typical diameter of $25-30 \mathrm{~cm}$ and the operation pressure is 10-20 bar. ${ }^{142}$ Using such an infrastructure to transport hydrogen is not feasible in many cases without substantial modifications to reduce diffusion losses in sealing areas as well as materials and seals embrittlement. ${ }^{143}$ In addition, the minimum power required to pump a gas through the pipe follows the equation below:

$$
P=8 \pi l v^{2} \eta
$$

where $l$ is the length of the pipe, and $v$ and $\eta$ are the velocity and dynamic viscosity of the gas. The volumetric density of hydrogen is $36 \%$ of the density of natural gas at the same pressure, and the viscosity of hydrogen is $\mathbf{8 0 \%}$ of that of natural gas. Therefore, to pump the same amount of hydrogen, the power needed is 2.2 times that for natural gas. ${ }^{142}$

\section{The role of enabling policies}

Today, hydrogen is mainly used for the production of ammonia and hydrocracking processes, with only a small portion used in the transport sector including in the nascent fleet of fuel cell vehicles. Uncertainties in technological development and price advantage of fossil fuel present a major challenge for the growth of renewable hydrogen at the industrial scale. Industry faces national and international competitive pressures, and existing economic models are highly sensitive to feedstock prices. Projections from the International Partnership for the Hydrogen Economy (IPHE) assume that hydrogen will continue to be produced from cheaper fossil fuels before renewable hydrogen can play a significant role. However, continuing declining prices of wind turbines, ${ }^{176}$ solar $\mathrm{PV},{ }^{177}$ and electrolys$\mathrm{ers}^{178}$ suggests that the production of hydrogen via power-to-gas 
(PtG) may become economically favorable in the next decade. ${ }^{179}$ For example, case studies have found that renewable hydrogen is already cost competitive in small- and mediumscaled applications combining renewable wind energy with a PtG facility. ${ }^{179}$ In this transition, it is often envisaged that carbon capture and storage may assist the production of low-carbon emission hydrogen from natural gas and coal, although currently not competitive. ${ }^{180}$ Solutions still remain to be found to effectively capture and store carbon dioxide, without mentioning the social licence aspects of such a solution. ${ }^{180}$

Additionally, non-economic barriers hindering the deployment of hydrogen technologies and infrastructures have also been identified. ${ }^{181}$ This includes (i) complex procedures and lack of information and assistance to enable projects, (ii) lack of public knowledge and awareness of the renewable hydrogen, (iii) social acceptance of the safety of hydrogen-related technologies and infrastructures, and (iv) lack of government initiatives to facilitate the use of hydrogen technologies and infrastructure construction. Existing safety regulations along hydrogen production, distribution, and storage are also limiting factors. ${ }^{182}$

In recent years, many countries have announced ambitious initiatives and visions to utilize renewable hydrogen as an energy carrier and achieve the greenhouse gas emission targets following the Paris Agreement in November 2016. ${ }^{183}$ However, implementation toward an hydrogen economy is still distant and in the light of the COVID-19 pandemic lobbying toward business as usual is more than ever prevalent. Currently, there are more than 19 hydrogen strategies and roadmaps around the world. ${ }^{184}$ However, many countries aim to focus on hydrogen use across the transport sector and existing gas distribution and transmission networks, with little understanding of the potential of hydrogen in the industrial sector. The EU, France, and Norway in contrast have identified hydrogen as an industrial feedstock, and aims to focus their strategy in this area, ${ }^{184}$ while the transport sector is to remain mainly battery-driven.

Policy and pilot projects that could enable the use of renewable hydrogen in industry are still lacking because of the relativity high cost of renewable hydrogen (approximately $5.30 \$$ / $\left.\mathrm{kg} \mathrm{H} \mathrm{H}_{2}\right){ }^{185}$ Only a few countries offer subsidies, tax incentives, and rebates for investments in renewable hydrogen production. For example, in Norway, electricity used to electrolyse water for hydrogen production is tax exempt, and in the Netherlands, a subsidy of up to $€ 750,000$ supports hydrogen-related projects. ${ }^{182}$

Many of the current demonstration and commercialization projects along renewable hydrogen plants are initiated by industry only, with the private sector expected to invest more than $\$ 50$ billion in hydrogen projects by 2030 . For example, Shell and ITM Power planned to install a 10 MW electrolyser in its refining industry site in Germany in 2017. In many countries like the USA, Japan, and China, primary hydrogen investments remain toward the deployment of fuel cell vehicles and hydrogen refuelling stations. While the heavy industry sector is the largest consumer of hydrogen, this sector is more closely bound to emission reduction regulations, renewable energy mandates, and carbon markets, compared with other light industries. ${ }^{186}$
Currently, there is no standard for low-carbon hydrogen, and green hydrogen is not recognized as a renewable fuel in many countries and thus not accountable toward the renewable target set in the mobility sector. It is therefore essential for organizations and policymakers to develop appropriate national and international standards, regulations, and relevant hydrogen certifications. This will allow renewable hydrogen to be supported by climate policies, in the same way as renewable technologies. The system "CertifHy" proposed in Europe to evaluate the environmental value of hydrogen could be a starting model to trade certified hydrogen. In this system, $\mathrm{CO}_{2}$ emission levels $(91 \mathrm{~g}$ $\mathrm{CO}_{2} / \mathrm{MJ} \mathrm{H}_{2}$ ) of hydrogen produced from reforming natural gas are used as a reference point. Hydrogen produced with a $60 \%$ reduction from this level (i.e., $36.4 \mathrm{~g} \mathrm{CO} \mathrm{CO}_{2} / \mathrm{MJ} \mathrm{H}_{2}$ ) is defined as "Premium Hydrogen," while Premium hydrogen produced from renewable energy is defined as "Green Hydrogen." 187

Government policies need to be designed as a long-term and fair competition platform for the hydrogen sector, introducing both incentives and regulations. When designing regulations relating to greenhouse gases reduction for industry, it is essential to acknowledge the significance and feasibility of clean hydrogen. It is conceivable to make use of a certain percentage of clean hydrogen in industrial processes mandatory with targeted reductions in use of steam methane-reforming hydrogen. Meanwhile, long-term high-risk mitigation implementations and incentives, such as the subsidy of a percentage of the high capital expenditure or compensation via products, could be effective in stimulating the large-scale production and supply of clean hydrogen. This can possibly reduce the cost of clean hydrogen for consumers, accelerating its mass deployment across industry.

Finally, public awareness and acceptance toward hydrogen are also important factors. It is apparent that many citizens are not educated on the potential of renewable hydrogen and its benefits for the environment. ${ }^{181}$ Even though the social acceptance of new technologies is considerably high in many European countries, hydrogen is still considered dangerous due to its high flammability. It is therefore important to demonstrate and implement a production of hydrogen that is safe to gain an increase in public support.

\section{Summary and perspectives}

As a crucial reactant for the chemical industry, the demand for hydrogen has grown considerably and will continue to rise in the foreseeable future. However, with most of the industrial hydrogen being sourced from fossil fuels, it is imperative that we start looking into sustainable production methods for hydrogen to succeed as a clean chemical feedstock and an energy carrier. Currently, only a small fraction of hydrogen is produced from renewable sources due to slow technological advances, lack of mass scale manufacturing of hydrogen technologies, and thus a high cost of green hydrogen relative to fossil fuels, and the lack of environmental government policies promoting 
the use of clean hydrogen. A few emerging technologies look promising based on the 2020 DOE target and even appear cost competitive to steam methane reforming for hydrogen production. However, the calculated production costs often do not tell the whole story; for example, electrolysis via geothermal and hydropower has a low cost of 1.1-2.4 $\$ / \mathrm{kg} \mathrm{H}_{2}$ but unfortunately their use is restricted by the geographic location of the energy source. Biochemically processed biomass also appears cost competitive at 1.4-2.8 $\$ / \mathrm{kg} \mathrm{H}_{2}$, but as an emerging technology, its reliability and actual cost at an industrial scale still remains to be determined. So far, wind-powered water electrolysis appears to have the best chance to play a major role in renewable hydrogen production due to the maturity and decreasing cost of wind technology. Once produced, the last hurdle for hydrogen is its storage and transport due to the low density of the gas. Until new methods like solid-state storage become more established, conventional methods (compressed gas cylinders and liquefied hydrogen) will remain the norm to get hydrogen to its end applications. Advancements in technological processes, cost, and policies still need to be conjointly progressed before renewable hydrogen can become the mainstream.

\section{REFERENCES:}

1. IEA: The Future of Hydrogen (International Energy Agency, 2019), Paris.

2. Klerke A., Christensen C.H., Nørskov J.K., and Vegge T.: Ammonia for hydrogen storage: Challenges and opportunities. J. Mater. Chem. 18, 2304 (2008).

3. Navarro R.M., Peña M.A., and Fierro J.L.G.: Hydrogen production reactions from carbon feedstocks: Fossil fuels and biomass. Chem. Rev 107, 3952 (2007).

4. International Council of Chemical Associations DECHEMA: Technology Roadmap: Energy and GHG Reductions in the Chemical Industry Via Catalytic Processes (International Energy Agency (IEA), 2013), Paris, France.

5. Veldsink J.W., Bouma M.J., Schöön N.H., and Beenackers A.A.C.M.: Heterogeneous hydrogenation of vegetable oils: A literature review. Catal. Rev. 39, 253 (1997).

6. Allen R.R.: Hydrogenation. J. Am. Oil Chem. Soc. 58, 166 (1981).

7. Wurster O.H.: Hydrogenation of fats. Ind. Eng. Chem. 32, 1193 (1940).

8. Dhaka V., Gulia N., Ahlawat K.S., and Khatkar B.S.: Trans fats sources, health risks and alternative approach - A review. J. Food Sci. Technol. 48, 534 (2011).

9. Lee I., Delbecq F., Morales R., Albiter M.A., and Zaera F.: Tuning selectivity in catalysis by controlling particle shape. Nat. Mater. 8, 132 (2009).

10. Philippaerts A., Jacobs P.A., and Sels B.F.: Is there still a future for hydrogenated vegetable oils? Angew. Chem. Int. Ed. 52, 5220 (2013).

11. Demirbas A.: Hydrogen production from carbonaceous solid wastes by steam reforming. Energy Sources A 30, 924 (2008).

12. Hosseini S.E. and Wahid M.A.: Hydrogen production from renewable and sustainable energy resources: Promising green energy carrier for clean development. Renew. Sustain. Energy Rev. 57, 850 (2016).

13. Lemus R.G. and Martínez Duart J.M.: Updated hydrogen production costs and parities for conventional and renewable technologies. Int. J. Hydrogen Energy 35, 3929 (2010).

14. M. Kayfeci, A. Keçebaş and M. Bayat: Chapter 3 - Hydrogen production. In Solar Hydrogen Production, Calise F., D’Accadia M.D., Santarelli M., Lanzini A. and Ferrero D., eds. (Academic Press, Cambridge, Massachusetts, US, 2019), p. 45.

15. El-Emam R.S. and Özcan H.: Comprehensive review on the techno-economics of sustainable large-scale clean hydrogen production. $J$. Clean. Prod. 220, 593 (2019).
16. Granados-Fernández R., Cortés-Reyes M., Poggio-Fraccari E., Herrera C., Larrubia MÁ, and Alemany L.J.: Biomass catalytic gasification performance over unsupported Ni-Ce catalyst for high-yield hydrogen production. Biofuel. Bioprod. Bioresour. 14, 20 (2019).

17. Resasco D.E., Wang B., and Sabatini D.: Distributed processes for biomass conversion could aid UN Sustainable Development Goals. Nat. Catal. 1, 731 (2018).

18. Navarro R.M., Sanchez-Sanchez M.C., Alvarez-Galvan M.C., del Valle F., and Fierro J.L.G.: Hydrogen production from renewable sources: Biomass and photocatalytic opportunities. Energy Environ. Sci. 2, 35 (2009).

19. Kalinci Y., Hepbasli A., and Dincer I.: Life cycle assessment of hydrogen production from biomass gasification systems. Int. J. Hydrogen Energy 37, 14026 (2012).

20. Arregi A., Amutio M., Lopez G., Bilbao J., and Olazar M.: Evaluation of thermochemical routes for hydrogen production from biomass: A review. Energy Convers. Manage. 165, 696 (2018).

21. Dou B.L., Zhang H., Song Y.C., Zhao L.F., Jiang B., He M.X., Ruan C.J., Chen H.S., and Xu Y.J.: Hydrogen production from the thermochemical conversion of biomass: Issues and challenges. Sust. Energy Fuels 3, 314 (2019).

22. Demirbas A.: Biorefineries: Current activities and future developments. Energy Convers. Manage. 50, 2782 (2009).

23. Zheng X., Ying Z., Wang B., and Chen C.: Hydrogen and syngas production from municipal solid waste (MSW) gasification via reusing $\mathrm{CO}_{2}$. Appl. Therm. Eng. 144, 242 (2018).

24. Pandey B., Prajapati Y.K., and Sheth P.N.: Recent progress in thermochemical techniques to produce hydrogen gas from biomass: A state of the art review. Int. J. Hydrogen Energy 44, 25384 (2019).

25. Formica M., Frigo S., and Gabbrielli R.: Development of a new steady state zero-dimensional simulation model for woody biomass gasification in a full scale plant. Energy Convers. Manage. 120, 358 (2016).

26. Cao L., Yu I.K.M., Xiong X., Tsang D.C.W., Zhang S., Clark J.H., Hu C., Ng Y.H., Shang J., and Ok Y.S.: Biorenewable hydrogen production through biomass gasification: A review and future prospects. Environ. Res. 186, 109547 (2020).

27. Mahidhara G., Burrow H., Sasikala C., and Ramana C.V.: Biological hydrogen production: Molecular and electrolytic perspectives. World J. Microbiol. Biotechnol. 35, 116 (2019).

28. Hallenbeck P.C. and Benemann J.R.: Biological hydrogen production: Fundamentals and limiting processes. Int. J. Hydrogen Energy 27, 1185 (2002).

29. Hirose A., Kasai T., Aoki M., Umemura T., Watanabe K., and Kouzuma A.: Electrochemically active bacteria sense electrode potentials for regulating catabolic pathways. Nat. Commun. 9, 1083 (2018).

30. Hirose A., Kasai T., Koga R., Suzuki Y., Kouzuma A., and Watanabe K.: Understanding and engineering electrochemically active bacteria for sustainable biotechnology. Bioresour. Bioprocess. 6 (2019).

31. Kadier A., Simayi Y., Abdeshahian P., Azman N.F., Chandrasekhar K., and Kalil M.S.: A comprehensive review of microbial electrolysis cells (MEC) reactor designs and configurations for sustainable hydrogen gas production. Alex. Eng. J. 55, 427 (2016).

32. Baeza J.A., Martínez-Miró À, Guerrero J., Ruiz Y., and Guisasola A.: Bioelectrochemical hydrogen production from urban wastewater on a pilot scale. J. Power Sources 356, 500 (2017).

33. Sun Y., He J., Yang G., Sun G., and Sage V.: A review of the enhancement of bio-hydrogen generation by chemicals addition. Catalysts 9, 353 (2019).

34. Tamburic B., Dechatiwongse P., Zemichael F.W., Maitland G.C., and Hellgardt K.: Process and reactor design for biophotolytic hydrogen production. Phys. Chem. Chem. Phys. 15, 10783 (2013).

35. Jabbari B., Jalilnejad E., Ghasemzadeh K., and Iulianelli A.: Recent progresses in application of membrane bioreactors in production of biohydrogen. Membranes 9, 100 (2019).

36. Fakhimi N. and Tavakoli O.: Improving hydrogen production using co-cultivation of bacteria with Chlamydomonas reinhardtii microalga. Mater. Sci. Energy Technol. 2, 1 (2019).

37. Kars G. and Alparslan Ü: Valorization of sugar beet molasses for the production of biohydrogen and 5-aminolevulinic acid by Rhodobacter 
sphaeroides O.U.001 in a biorefinery concept. Int. J. Hydrogen Energy 38, 14488 (2013).

38. Ghosh S., Dairkee U.K., Chowdhury R., and Bhattacharya P.: Hydrogen from food processing wastes via photofermentation using purple non-sulfur bacteria (PNSB) - A review. Energy Convers. Manage. 141, 299 (2017).

39. Zagrodnik R. and Laniecki M.: Hydrogen production from starch by co-culture of Clostridium acetobutylicum and Rhodobacter sphaeroides in one step hybrid dark- and photofermentation in repeated fed-batch reactor. Bioresour. Technol. 224, 298 (2017).

40. Słupek E., Kucharska K., and Gębicki J.: Alternative methods for dark fermentation course analysis. SN Appl. Sci. 1, 469 (2019).

41. Pendyala B., Chaganti S.R., Lalman J.A., Shanmugam S.R., Heath D.D., and Lau P.C.K.: Pretreating mixed anaerobic communities from different sources: Correlating the hydrogen yield with hydrogenase activity and microbial diversity. Int. J. Hydrogen Energy 37, 12175 (2012).

42. Dessì P., Porca E., Waters N.R., Lakaniemi A.-M., Collins G., and Lens P.N.L.: Thermophilic versus mesophilic dark fermentation in xylose-fed fluidised bed reactors: Biohydrogen production and active microbial community. Int. J. Hydrogen Energy 43, 5473 (2018).

43. Saghir M., Rehan M., and Nizami A.-S.: Recent Trends in Gasification Based Waste-to-Energy, Yongseung Yun, ed. (IntechOpen, London, UK, 2018).

44. Gai C., Guo Y., Liu T., Peng N., and Liu Z.: Hydrogen-rich gas production by steam gasification of hydrochar derived from sewage sludge. Int. J. Hydrogen Energy 41, 3363 (2016).

45. Shahbaz M., Yusup S., Inayat A., Patrick D.O., and Ammar M.: The influence of catalysts in biomass steam gasification and catalytic potential of coal bottom ash in biomass steam gasification: A review. Renew. Sustain. Energy Rev. 73, 468 (2017).

46. Lv P.M., Xiong Z.H., Chang J., Wu C.Z., Chen Y., and Zhu J.X.: An experimental study on biomass air-steam gasification in a fluidized bed. Bioresour. Technol. 95, 95 (2004).

47. Rapagnà S., Jand N., Kiennemann A., and Foscolo P.U.: Steam-gasification of biomass in a fluidised-bed of olivine particles. Biomass Bioenergy 19, 187 (2000).

48. Kang K., Azargohar R., Dalai A.K., and Wang H.: Hydrogen production from lignin, cellulose and waste biomass via supercritical water gasification: Catalyst activity and process optimization study. Energy Convers. Manage. 117, 528 (2016).

49. Iribarren D., Peters J.F., and Dufour J.: Life cycle assessment of transportation fuels from biomass pyrolysis. Fuel 97, 812 (2012).

50. Schuster G., Löffler G., Weigl K., and Hofbauer H.: Biomass steam gasification - An extensive parametric modeling study. Bioresour. Technol. 77, 71 (2001).

51. Gil J., Corella J., Aznar M.P., and Caballero M.A.: Biomass gasification in atmospheric and bubbling fluidized bed: Effect of the type of gasifying agent on the product distribution. Biomass Bioenergy 17, 389 (1999).

52. Balat M.: Hydrogen-rich gas production from biomass via pyrolysis and gasification processes and effects of catalyst on hydrogen yield. Energy Sources A 30, 552 (2008).

53. Anca-Couce A.: Reaction mechanisms and multi-scale modelling of lignocellulosic biomass pyrolysis. Prog. Energy Combust. Sci. 53, 41 (2016).

54. Duman G. and Yanik J.: Two-step steam pyrolysis of biomass for hydrogen production. Int. J. Hydrogen Energy 42, 17000 (2017).

55. Waheed Q.M.K. and Williams P.T.: Hydrogen production from high temperature pyrolysis/steam reforming of waste biomass: Rice husk, sugar cane bagasse, and wheat straw. Energy Fuels 27, 6695 (2013).

56. L. He, J. Yang and D. Chen: Hydrogen from biomass: advances in thermochemical processes. In Renewable Hydrogen Technologies Production, Purification, Storage, Applications and Safety, Luis Gandia, ed. (Elsevier, Amsterdam, Netherlands, 2013), pp. 111.

57. Qiu P., Du C., Liu L., and Chen L.: Hydrogen and syngas production from catalytic steam gasification of char derived from ion-exchangeable Na- and Ca-loaded coal. Int. J. Hydrogen Energy 43, 12034 (2018).

58. Cao L., Chen H., Tsang D.C.W., Luo G., Hao S., Zhang S., and Chen J.: Optimizing xylose production from pinewood sawdust through dilute-phosphoric-acid hydrolysis by response surface methodology. $J$. Clean. Prod. 178, 572 (2018).
59. Ebadi A.G., Hisoriev H., Zarnegar M., and Ahmadi H.: Hydrogen and syngas production by catalytic gasification of algal biomass (Cladophora glomerata L.) using alkali and alkaline-earth metals compounds. Environ. Technol. 40, 1178 (2019).

60. Bobadilla L.F., Álvarez A., Domínguez M.I., Romero-Sarria F., Centeno M.A., Montes M., and Odriozola J.A.: Influence of the shape of Ni catalysts in the glycerol steam reforming. Appl. Catal. B 123-124, 379 (2012).

61. Sun J., Mei D., Karim A.M., Datye A.K., and Wang Y.: Minimizing the formation of coke and methane on Co nanoparticles in steam reforming of biomass-derived oxygenates. ChemCatChem 5, 1299 (2013).

62. Nieva M.A., Villaverde M.M., Monzón A., Garetto T.F., and Marchi A.J.: Steam-methane reforming at low temperature on nickel-based catalysts. Chem. Eng. J. 235, 158 (2014).

63. Men Y. and Yang M.: SMSI-like behavior and Ni promotion effect on NiZnAl catalysts in steam reforming of methanol. Catal. Commun. 22, 68 (2012).

64. Zhang L., Pan L., Ni C., Sun T., Zhao S., Wang S., Wang A., and Hu Y.: $\mathrm{CeO}_{2}-\mathrm{ZrO}_{2}$-promoted $\mathrm{CuO} / \mathrm{ZnO}$ catalyst for methanol steam reforming. Int. J. Hydrogen Energy 38, 4397 (2013).

65. Li D., Tamura M., Nakagawa Y., and Tomishige K.: Metal catalysts for steam reforming of tar derived from the gasification of lignocellulosic biomass. Bioresour. Technol. 178, 53 (2015).

66. Iulianelli A., Palma V., Bagnato G., Ruocco C., Huang Y., Veziroğlu N.T., and Basile A.: From bioethanol exploitation to high grade hydrogen generation: Steam reforming promoted by a Co-Pt catalyst in a Pd-based membrane reactor. Renew. Energy 119, 834 (2018).

67. Iida H., Noguchi K., Numa T., Igarashi A., and Okumura K.: Ru/12SrO$7 \mathrm{Al}_{2} \mathrm{O}_{3}$ (S12A7) catalyst prepared by physical mixing with $\mathrm{Ru}\left(\mathrm{PPh}_{3}\right)_{3} \mathrm{Cl}_{2}$ for steam reforming of toluene. Catal. Commun. 72, 101 (2015).

68. Basu S. and Pradhan N.C.: Selective production of hydrogen by acetone steam reforming over Ni-Co/olivine catalysts. React. Kinet. Mech. Catal. 127, 357 (2019).

69. Ma X., Zhao X., Gu J., and Shi J.: Co-gasification of coal and biomass blends using dolomite and olivine as catalysts. Renew. Energy 132, 509 (2019).

70. Wu H., La Parola V., Pantaleo G., Puleo F., Venezia A., and Liotta L.: Ni-based catalysts for low temperature methane steam reforming: Recent results on Ni-Au and comparison with other Bi-metallic systems. Catalysts 3,563 (2013).

71. Palma V., Ruocco C., Meloni E., and Ricca A.: Renewable hydrogen from ethanol reforming over $\mathrm{CeO}_{2}-\mathrm{SiO}_{2}$ based catalysts. Catalysts 7, 226 (2017).

72. Marcoberardino G.D., Vitali D., Spinelli F., Binotti M., and Manzolini G.: Green hydrogen production from raw biogas: A techno-economic investigation of conventional processes using pressure swing adsorption unit. Processes 6, 19 (2018).

73. Ewan B.C.R. and Allen R.W.K.: A figure of merit assessment of the routes to hydrogen. Int. J. Hydrogen Energy 30, 809 (2005).

74. Chi J. and Yu H.: Water electrolysis based on renewable energy for hydrogen production. Chinese J. Catal. 39, 390 (2018).

75. Safari F. and Dincer I.: A review and comparative evaluation of thermochemical water splitting cycles for hydrogen production. Energy Convers. Manage. 205, 112182 (2020).

76. Colón G.: Towards the hydrogen production by photocatalysis. Appl. Catal. 518, 48 (2016).

77. Ismail A.A. and Bahnemann D.W.: Photochemical splitting of water for hydrogen production by photocatalysis: A review. Sol. Energy Mater. Sol. Cells 128, 85 (2014).

78. Samokhvalov A.: Hydrogen by photocatalysis with nitrogen codoped titanium dioxide. Renew. Sustain. Energ. Rev. 72, 981 (2017).

79. Castelli I.E., Landis D.D., Thygesen K.S., Dahl S., Chorkendorff I., Jaramillo T.F., and Jacobsen K.W.: New cubic perovskites for one- and two-photon water splitting using the computational materials repository. Energy Environ. Sci. 5, 9034 (2012).

80. Cao S. and $\mathrm{Yu}$ J.: g- $\mathrm{C}_{3} \mathrm{~N}_{4}$-based photocatalysts for hydrogen generation. J. Phys. Chem. Lett. 5, 2101 (2014).

81. Li R., Han H., Zhang F., Wang D., and Li C.: Highly efficient photocatalysts constructed by rational assembly of dual-cocatalysts separately on different facets of $\mathrm{BiVO}_{4}$. Energy Environ. Sci. 7, 1369 (2014). 
82. Ran J., Zhang J., Yu J., and Qiao S.Z.: Enhanced visible-light photocatalytic $\mathrm{H}_{2}$ production by $\mathrm{Zn}_{x} \mathrm{Cd}_{1-x} \mathrm{~S}$ modified with earth-abundant nickel-based cocatalysts. ChemSusChem 7, 3426 (2014).

83. Young J.L., Steiner M.A., Döscher H., France R.M., Turner J.A., and Deutsch T.G.: Direct solar-to-hydrogen conversion via inverted metamorphic multi-junction semiconductor architectures. Nat. Energy 2, 1 (2017).

84. Miller E.L.: Photoelectrochemical water splitting. Energy Environ. Sci. 8, 2809 (2015).

85. Pinaud B.A., Benck J.D., Seitz L.C., Forman A.J., Chen Z., Deutsch T.G., James B.D., Baum K.N., Baum G.N., Ardo S., Wang H., Miller E., and Jaramillo T.F.: Technical and economic feasibility of centralized facilities for solar hydrogen production via photocatalysis and photoelectrochemistry. Energy Environ. Sci. 6, 1983 (2013).

86. Rashwan S.S., Dincer I., Mohany A., and Pollet B.G.: The Sono-Hydro-Gen process (ultrasound induced hydrogen production): Challenges and opportunities. Int. J. Hydrogen Energy 44, 14500 (2019).

87. Bhosale R.R., Kumar A., and Sutar P.: Thermodynamic analysis of solar driven $\mathrm{SnO}_{2} / \mathrm{SnO}$ based thermochemical water splitting cycle. Energy Convers. Manage. 135, 226 (2017).

88. Graf D., Monnerie N., Roeb M., Schmitz M., and Sattler C.: Economic comparison of solar hydrogen generation by means of thermochemical cycles and electrolysis. Int. J. Hydrogen Energy 33, 4511 (2008).

89. Charvin P., Stéphane A., Florent L., and Gilles F.: Analysis of solar chemical processes for hydrogen production from water splitting thermochemical cycles. Energy Convers. Manage. 49, 1547 (2008).

90. Millet P., Mbemba N., Grigoriev S.A., Fateev V.N., Aukauloo A., and Etiévant C.: Electrochemical performances of PEM water electrolysis cells and perspectives. Int. J. Hydrogen Energy 36, 4134 (2011).

91. Selamet ÖF, Becerikli F., Mat M.D., and Kaplan Y.: Development and testing of a highly efficient proton exchange membrane (PEM) electrolyzer stack. Int. J. Hydrogen Energy 36, 11480 (2011).

92. Yin Y., Wang X., Zhang J., Shangguan X., and Qin Y.: Influence of sloping baffle plates on the mass transport and performance of PEMFC. Int. J. Energy Res. 43 (2018).

93. Carmo M., Fritz D.L., Mergel J., and Stolten D.: A comprehensive review on PEM water electrolysis. Int. J. Hydrogen Energy 38, 4901 (2013).

94. Grigoriev S.A., Porembsky V.I., and Fateev V.N.: Pure hydrogen production by PEM electrolysis for hydrogen energy. Int. J. Hydrogen Energy 31, 171 (2006).

95. Phillips R. and Dunnill C.: Zero gap alkaline electrolysis cell design for renewable energy storage as hydrogen gas. RSC Adv. 6, 100643 (2016).

96. Rashid M., Al Mesfer M., Naseem H., and Danish M.: Hydrogen production by water electrolysis: A review of alkaline water electrolysis, PEM water electrolysis and high temperature water electrolysis. Int. J. Eng. Adv. Technol. 4, 2249 (2015).

97. Leng Y., Chen G., Mendoza A.J., Tighe T.B., Hickner M.A., and Wang C.-Y.: Solid-state water electrolysis with an alkaline membrane. J. Am. Chem. Soc. 134, 9054 (2012).

98. Pavel C., Cecconi F., Emiliani C., Santiccioli S., Scaffidi A., Catanorchi S., and Comotti M.: Highly efficient platinum group metal free based membrane-electrode assembly for anion exchange membrane water electrolysis. Angew. Chem. Int. Ed. 126, 1378 (2014).

99. Moçoteguy P. and Brisse A.: A review and comprehensive analysis of degradation mechanisms of solid oxide electrolysis cells. Int. J. Hydrogen Energy 38, 15887 (2013).

100. Kadier A., Kalil M.S., Abdeshahian P., Chandrasekhar K., Mohamed A., Azman N.F., Logroño W., Simayi Y., and Hamid A.A.: Recent advances and emerging challenges in microbial electrolysis cells (MECs) for microbial production of hydrogen and value-added chemicals. Renew. Sustain. Energy Rev. 61, 501 (2016)

101. Zeng K. and Zhang D.: Recent progress in alkaline water electrolysis for hydrogen production and applications. Prog. Energy Combust. Sci. 36, 307 (2010).

102. Wendt H. and Hofmann H.: Ceramic diaphragms for advanced alkaline water electrolysis. J. Appl. Electrochem. 19, 605 (1989).
103. Ayers K.E., Capuano C., and Anderson E.B.: Recent advances in cell cost and efficiency for PEM-based water electrolysis. ECS Transactions 41, 15 (2019).

104. Bose R., Karuppasamy K., Rajan H., Velusamy D., Kim H.-S., and Alfantazi A.: Electrodeposition of unary oxide on a bimetallic hydroxide as a highly active and stable catalyst for water oxidation. ACS Sustain. Chem. Eng. 7, 16392 (2019).

105. Truong L., Jerng S.-K., Roy S.B., Jeon J.H., Kim K., Akbar K., Yi Y., and Chun S.-H.: Chrysanthemum-like CoP nanostructures on vertical graphene nanohills as versatile electrocatalysts for water splitting. ACS Sustain. Chem. Eng. 7, 4625 (2019).

106. He M., Feng C., Liao T., Hu S., Wu H., and Sun Z.: Low-cost $\mathrm{Ni}_{2} \mathrm{P} / \mathrm{Ni}_{0.96} \mathrm{~S}$ heterostructured bifunctional electrocatalyst toward highly efficient overall urea-water electrolysis. ACS Appl. Mater. Interfaces 12, 2225 (2020).

107. Siracusano S., Van Dijk N., Backhouse R., Merlo L., Baglio V., and Aricò A.S.: Degradation issues of PEM electrolysis MEAs. Renew. Energy 123, 52 (2018).

108. Frensch S.H., Fouda-Onana F., Serre G., Thoby D., Araya S.S., and Kær S.K.: Influence of the operation mode on PEM water electrolysis degradation. Int. J. Hydrogen Energy 44, 29889 (2019).

109. Ferriday T. and Middleton P.H.: Experimental analysis of materials in proton exchange membrane electrolysis cells. Int. J. Hydrogen Energy 44, 27656 (2019).

110. García-Osorio D., Jaimes R., Vazquez-Arenas J., Lara R., and Alvarez-Ramirez J.: The kinetic parameters of the oxygen evolution reaction (OER) calculated on inactive anodes via EIS transfer functions: $\mathrm{OH}$ formation. J. Electrochem. Soc. 164, E1 (2017).

111. Yu J., He Q., Yang G., Zhou W., Shao Z., and Ni M.: Recent advances and prospective in ruthenium-based materials for electrochemical water splitting. ACS Catal. 9, 9973 (2019).

112. Wang D., Song Y., Zhang H., Yan X., and Guo J.: Recent advances in transition metal borides for electrocatalytic oxygen evolution reaction. $J$. Electroanal. Chem. 861, 113953 (2020).

113. Pareek A., Dom R., Gupta J., Chandran J., Adepu V., and Borse P.H.: Insights into renewable hydrogen energy: Recent advances and prospects. Mater. Sci. Energy Technol. 3, 319 (2020).

114. Weigt H.: Germany's wind energy: The potential for fossil capacity replacement and cost saving. Appl. Energy 86, 1857 (2009).

115. Greiner C.J., Korpas M., and Holen A.T.: A Norwegian case study on the production of hydrogen from wind power. Int. J. Hydrogen Energy 32, 1500 (2007).

116. Ayodele T.R. and Munda J.L.: Potential and economic viability of green hydrogen production by water electrolysis using wind energy resources in South Africa. Int. J. Hydrogen Energy 44, 17669 (2019).

117. Rezaei M., Naghdi-Khozani N., and Jafari N.: Wind energy utilization for hydrogen production in an underdeveloped country: An economic investigation. Renew. Energy 147, 1044 (2020).

118. Nadaleti W.C., Borges dos Santos G., and Lourenço V.A.: The potential and economic viability of hydrogen production from the use of hydroelectric and wind farms surplus energy in Brazil: A national and pioneering analysis. Int. J. Hydrogen Energy 45, 1373 (2020).

119. Jørgensen C. and Ropenus S.: Production price of hydrogen from grid connected electrolysis in a power market with high wind penetration. Int. J. Hydrogen Energy 33, 5335 (2008).

120. Mueller-Langer F., Tzimas E., Kaltschmitt M., and Peteves S.: Techno-economic assessment of hydrogen production processes for the hydrogen economy for the short and medium term. Int. J. Hydrogen Energy 32,3797 (2007)

121. Bazilian M., Onyeji I., Liebreich M., MacGill I., Chase J., Shah J., Gielen D., Arent D., Landfear D., and Zhengrong S.: Re-considering the economics of photovoltaic power. Renew. Energy 53, 329 (2013).

122. Lagorse J., Simões M.G., Miraoui A., and Costerg P.: Energy cost analysis of a solar-hydrogen hybrid energy system for stand-alone applications. Int. J. Hydrogen Energy 33, 2871 (2008).

123. Mason J.E. and Zweibel K.: Baseline model of a centralized pv electrolytic hydrogen system. Int. J. Hydrogen Energy 32, 2743 (2007). 
124. Kikuchi Y., Ichikawa T., Sugiyama M., and Koyama M.: Battery-assisted low-cost hydrogen production from solar energy: Rational target setting for future technology systems. Int. J. Hydrogen Energy 44, 1451 (2019).

125. Fereidooni M., Mostafaeipour A., Kalantar V., and Goudarzi H.: A comprehensive evaluation of hydrogen production from photovoltaic power station. Renew. Sust. Energ. Rev. 82, 415 (2018).

126. Al-Sharafi A., Sahin A.Z., Ayar T., and Yilbas B.S.: Techno-economic analysis and optimization of solar and wind energy systems for power generation and hydrogen production in Saudi Arabia. Renew. Sustain. Energy Rev. 69, 33 (2017).

127. Dufo-López R., Bernal-Agustín J.L., and Mendoza F.: Design and economical analysis of hybrid PV-wind systems connected to the grid for the intermittent production of hydrogen. Energy Policy 37, 3082 (2009).

128. Dagdougui H., Ouammi A., and Sacile R.: A regional decision support system for onsite renewable hydrogen production from solar and wind energy sources. Int. J. Hydrogen Energy 36, 14324 (2011).

129. Temiz M. and Javani N.: Design and analysis of a combined floating photovoltaic system for electricity and hydrogen production. Int. J. Hydrogen Energy 45, 3457 (2020).

130. Olateju B. and Kumar A.: A techno-economic assessment of hydrogen production from hydropower in Western Canada for the upgrading of bitumen from oil sands. Energy 115, 604 (2016).

131. Yilmaz C., Koyuncu I., Alcin M., and Tuna M.: Artificial neural networks based thermodynamic and economic analysis of a hydrogen production system assisted by geothermal energy on field programmable gate array. Int. J. Hydrogen Energy 44, 17443 (2019).

132. Hsu C.-H., Chang C.-C., Tseng C.-M., Chan C.-C., Chao W.-H., Wu Y.-R., Wen M.-H., Hsieh Y.-T., Wang Y.-C., and Chen C.-L.: An ultra-fast response gasochromic device for hydrogen gas detection. Sens. Actuators B 186, 193 (2013).

133. Sherif S.A., Barbir F., and Veziroglu T.N.: Wind energy and the hydrogen economy - review of the technology. Sol. Energy 78, 647 (2005).

134. Louthan M.R.: Hydrogen embrittlement of metals: A primer for the failure analyst. J. Fail. Anal. Prev. 8, 289 (2008).

135. Rogers H.C.: Hydrogen embrittlement of metals: Atomic hydrogen from a variety of sources reduces the ductility of many metals. Science 159, 1057 (1968).

136. Zheng J., Liu X., Xu P., Liu P., Zhao Y., and Yang J.: Development of high pressure gaseous hydrogen storage technologies. Int. J. Hydrogen Energy 37, 1048 (2012).

137. Alazemi J. and Andrews J.: Automotive hydrogen fuelling stations: An international review. Renew. Sustain. Energy Rev. 48, 483 (2015).

138. Dagdougui H., Sacile R., Bersani C., and Ouammi A.: Hydrogen Infrastructure for Energy Applications: Production, Storage, Distribution and Safety (Academic Press, Cambridge, MA, USA, 2018).

139. Malakhov A.A., Avdeenkov A.V., du Toit M.H., and Bessarabov D.G.: CFD simulation and experimental study of a hydrogen leak in a semi-closed space with the purpose of risk mitigation. Int. J. Hydrogen Energy 45, 9231 (2020).

140. Mazloomi K. and Gomes C.: Hydrogen as an energy carrier: Prospects and challenges. Renew. Sustain. Energy Rev. 16, 3024 (2012).

141. Villalonga S., Nony F., Magnier C., Yvernes J., Thomas C., Delmas B., and Mazabraud P.: Composite 700 bar-vessel for on-board compressed gaseous hydrogen storage. In Proceeding of 17th International Conference on Composite Materials, Edinburgh, UK (2009).

142. Züttel A.: Hydrogen storage methods. Naturwissenschaften 91, 157 (2004).

143. Bossel U.: Does a hydrogen economy make sense? In Proceedings of the IEEE (2006), p. 1826.

144. Zhou L.: Progress and problems in hydrogen storage methods. Renew. Sustain Energy Rev. 9, 395 (2005).

145. Züttel A.: Materials for hydrogen storage. Mater. Today 6, 24 (2003).

146. Li Y., Chen H., Zhang X., Tan C., and Ding Y.: Renewable energy carriers: Hydrogen or liquid air/nitrogen? Appl. Therm. Eng. 30, 1985 (2010).

147. Schlapbach L. and Zuttel A.: Hydrogen-storage materials for mobile applications. Nature 414, 353 (2001).

148. Nijkamp M., Raaymakers J., Van Dillen A., and De Jong K.: Hydrogen storage using physisorption-materials demands. Appl. Phys. A 72, 619 (2001).
149. Blankenship T.S. II, Balahmar N., and Mokaya R.: Oxygen-rich microporous carbons with exceptional hydrogen storage capacity. Nat. Commun. 8, 1 (2017).

150. Zhou L., Liu D., Li J., Tang H., Xie Z., and Qu D.: Electrochemical hydrogen storage in a nitrogen-doped uniformed microporous carbon. Int. J. Hydrogen Energy 43, 14096 (2018).

151. Li Y., Liu H., Yang C., Zhu M., and Chen T.: The activation and hydrogen storage characteristics of the cup-stacked carbon nanotubes. Diamond Relat. Mater. 100, 107567 (2019).

152. Mohan M., Sharma V.K., Kumar E.A., and Gayathri V.: Hydrogen storage in carbon materials-A review. Energy Storage 1, E35 (2019).

153. Weitkamp J., Fritz M., and Ernst S.: Zeolites as media for hydrogen storage. Int. J. Hydrogen Energy 20, 967 (1995).

154. Yang Z., Xia Y., and Mokaya R.: Enhanced hydrogen storage capacity of high surface area zeolite-like carbon materials. J. Am. Chem. Soc. 129, 1673 (2007).

155. Molefe L.Y., Musyoka N.M., Ren J., Langmi H.W., Mathe M., and Ndungu P.G.: Polymer-based shaping strategy for zeolite templated carbon (ZTC) and their metal organic framework (MOF) composites for improved hydrogen storage properties. Front. Chem. 7, 864 (2019).

156. Ismail N. and Tantawy H.A.: Microwave synthesis of nano/micronized zeolites from natural source: Evaluation of energy storage capacities. Egypt. J. Chem. 63, 8 (2020).

157. Bose R., Ethiraj J., Sridhar P., Varghese J.J., Kaisare N.S., and Selvam P.: Adsorption of hydrogen and carbon dioxide in zeolitic imidazolate framework structure with SOD topology: Experimental and modelling studies. Adsorption 1 (2020).

158. Xu J., Liu J., Li Z., Wang X., Xu Y., Chen S., and Wang Z.: Optimized synthesis of $\mathrm{Zr}$ (IV) metal organic frameworks (MOFs-808) for efficient hydrogen storage. New J. Chem. 43, 4092 (2019).

159. Suh M.P., Park H.J., Prasad T.K., and Lim D.W.: Hydrogen storage in metal-organic frameworks. Chem. Rev. 112, 782 (2012).

160. Murray L.J., Dinca M., and Long J.R.: Hydrogen storage in metal-organic frameworks. Chem. Soc. Rev. 38, 1294 (2009).

161. Rowsell J.L.C. and Yaghi O.M.: Strategies for hydrogen storage in metal-organic frameworks. Angew. Chem. Int. Ed. 44, 4670 (2005).

162. Gangu K.K., Maddila S., Mukkamala S.B., and Jonnalagadda S.B.: Characteristics of MOF, MWCNT and graphene containing materials for hydrogen storage: A review.J. Energy Chem. 30, 132 (2019).

163. Bobbitt N.S. and Snurr R.Q.: Molecular modelling and machine learning for high-throughput screening of metal-organic frameworks for hydrogen storage. Mol. Simulat. 45, 1069 (2019).

164. Lim K.L., Kazemian H., Yaakob Z., and Daud W.R.W.: Solid-state materials and methods for hydrogen storage: A critical review. Chem. Eng. Technol. 33, 213 (2010).

165. Ramimoghadam D., Gray E.M., and Webb C.J.: Review of polymers of intrinsic microporosity for hydrogen storage applications. Int. J. Hydrogen Energy 41, 16944 (2016).

166. Lai Q., Sun Y., Wang T., Modi P., Cazorla C., Demirci U.B., Ares Fernandez J.R., Leardini F., and Aguey-Zinsou K.F.: How to design hydrogen storage materials? Fundamentals, synthesis, and storage tanks. Adv. Sustain. Syst. 3, 1900043 (2019).

167. Zhang F., Zhao P., Niu M., and Maddy J.: The survey of key technologies in hydrogen energy storage. Int. J. Hydrogen Energy 41, 14535 (2016).

168. Sujan G., Pan Z., Li H., Liang D., and Alam N.: An overview on TiFe intermetallic for solid-state hydrogen storage: Microstructure, hydrogenation and fabrication processes. Crit. Rev. Solid State Mater. Sci. 1, 1 (2019).

169. Kumar S., Kojima Y., and Dey G.K.: Thermodynamics and kinetics of hydrogen absorption-desorption of highly crystalline $\mathrm{LaNi}_{5}$. J. Therm. Anal. Calorim. 134, 889 (2018).

170. Broom D.P.: Hydrogen Storage Materials: The Characterisation of Their Storage Properties (Springer Science \& Business Media, Berlin, Germany, 2011).

171. Dalebrook A.F., Gan W., Grasemann M., Moret S., and Laurenczy G.: Hydrogen storage: Beyond conventional methods. Chem. Commun. 49, 8735 (2013). 
172. Wang T. and Aguey-Zinsou K.F.: Controlling the growth of $\mathrm{LiBH}_{4}$ nanoparticles for hydrogen storage. Energy Technol. 7, 1801159 (2019).

173. Benzidi H., Lakhal M., Abdellaoui M., Garara M., Benyoussef A., Loulidi M., Hamedoun M., and Mounkachi O.: Improved thermodynamic properties of doped $\mathrm{LiBH}_{4}$ for hydrogen storage: First-principal calculation. Int. J. Hydrogen Energy 44, 16793 (2019).

174. Sinigaglia T., Lewiski F., Martins M.E.S., and Siluk J.C.M.: Production, storage, fuel stations of hydrogen and its utilization in automotive applications - a review. Int. J. Hydrogen Energy 42, 24597 (2017).

175. Li X.J., Allen J.D., Stager J.A., and Ku A.Y.: Paths to low-cost hydrogen energy at a scale for transportation applications in the USA and China via liquid-hydrogen distribution networks. Clean Energy 4, 26 (2020).

176. Wiser R., Jenni K., Seel J., Baker E., Hand M., Lantz E., and Smith A.: Expert elicitation survey on future wind energy costs. Nat. Energy 1, 1 (2016).

177. Comello S., Reichelstein S., and Sahoo A.: The road ahead for solar PV power. Renew. Sustain. Energy Rev. 92, 744 (2018).

178. Felgenhauer M. and Hamacher T.: State-of-the-art of commercial electrolyzers and on-site hydrogen generation for logistic vehicles in South Carolina. Int. J. Hydrogen Energy 40, 2084 (2015).

179. Glenk G. and Reichelstein S.: Economics of converting renewable power to hydrogen. Nat. Energy 4, 216 (2019).

180. National Research Council: The Hydrogen Economy: Opportunities, Costs, Barriers, and R\&D Needs (National Academies Press, Washington, D.C., USA, 2004).
181. Garcia D.A.: Analysis of non-economic barriers for the deployment of hydrogen technologies and infrastructures in European countries. Int. J. Hydrogen Energy 42, 6435 (2017).

182. Dolci F., Thomas D., Hilliard S., Guerra C.F., Hancke R., Ito H., Jegoux M., Kreeft G., Leaver J., Newborough M., Proost J., Robinius M., Weidner E., Mansilla C., and Lucchese P.: Incentives and legal barriers for power-to-hydrogen pathways: An international snapshot. Int. J. Hydrogen Energy 44, 11394 (2019).

183. Rogelj J., Den Elzen M., Höhne N., Fransen T., Fekete H., Winkler H., Schaeffer R., Sha F., Riahi K., and Meinshausen M.: Paris Agreement climate proposals need a boost to keep warming well below $2^{\circ} \mathrm{C}$. Nature 534,631 (2016).

184. Kosturjak A., Dey T., Young M.D., and Whetton S.: Advancing Hydrogen: Learning From 19 Plans to Advance Hydrogen From Across the Globe (Future Fuels CRC, 2019), Australia.

185. Mohsin M., Rasheed A., and Saidur R.: Economic viability and production capacity of wind generated renewable hydrogen. Int. J. Hydrogen Energy 43, 2621 (2018)

186. Hydrogen From Renewable Power: Technology Outlook for the energy transition, (IRENA, International Renewable Energy Agency, 2018), Abu Dhabi.

187. Abad A.V. and Dodds P.E.: Green hydrogen characterisation initiatives: Definitions, standards, guarantees of origin, and challenges. Energy Policy $138,111300(2020)$. 